\title{
Mangrove Methane Biogeochemistry in the Indian Sundarbans: A Proposed Budget
}

\author{
Manab K. Dutta ${ }^{1,2}$, Thomas S. Bianchi ${ }^{3}$ and Sandip K. Mukhopadhyay ${ }^{1 *}$ \\ ${ }^{1}$ Department of Marine Science, University of Calcutta, Kolkata, India, ${ }^{2}$ Geosciences Division, Physical Research Laboratory, \\ Ahmedabad, India, ${ }^{3}$ Department of Geological Sciences, University of Florida, Gainesville, FL, United States
}

\section{OPEN ACCESS}

Edited by:

Selvaraj Kandasamy,

Xiamen University, China

Reviewed by:

Damien Troy Maher,

Southern Cross University, Australia

Jun Sun,

Tianjin University of Science and

Technology, China

Mengran Du,

Sanya Institute of Deep-Sea Science and Engineering (CAS), China

${ }^{*}$ Correspondence: Sandip K. Mukhopadhyay skm.caluniv@gmail.com

Specialty section: This article was submitted to Marine Biogeochemistry, a section of the journal Frontiers in Marine Science

Received: 14 February 2017 Accepted: 30 May 2017 Published: 13 June 2017

Citation:

Dutta MK, Bianchi TS and Mukhopadhyay SK (2017) Mangrove Methane Biogeochemistry in the Indian Sundarbans: A Proposed Budget. Front. Mar. Sci. 4:187. doi: 10.3389/fmars.2017.00187
Biogeochemical cycling of $\mathrm{CH}_{4}$ was investigated at Lothian Island, one of the relatively pristine islands of Indian Sundarbans and its adjacent Saptamukhi estuary, during June 2010 to December 2012. Intertidal mangrove sediments were highly anoxic and rich in organic carbon. Mean rates of methanogenesis were 3,547 and $48.88 \mu \mathrm{mol} \mathrm{m} \mathrm{m}^{-3}$ wet sediment $\mathrm{d}^{-1}$, for intertidal (up to $25 \mathrm{~cm}$ depth) and sub-tidal sediments (first $5 \mathrm{~cm}$ depth), respectively. $\mathrm{CH}_{4}$ in pore-water was 53.4 times more supersaturated than in adjacent estuarine waters. This resulted in significant $\mathrm{CH}_{4}$ efflux from sediments to estuarine waters-via advective and diffusive transport. About $8.2 \%$ of the total $\mathrm{CH}_{4}$ produced in intertidal mangrove sediments was transported to the adjacent estuary through advective flux, which was 20 times higher than diffusive $\mathrm{CH}_{4}$ flux. Mean $\mathrm{CH}_{4}$ concentrations in estuarine surface and sub-surface waters were 69.9 and $56.1 \mathrm{nM}$, respectively, with a dissolved $\mathrm{CH}_{4}$ oxidation rate in estuarine surface waters of $20.5 \mathrm{nmol} \mathrm{L} \mathrm{L}^{-1} \mathrm{~d}^{-1}$. An estimated $0.09 \mathrm{Gg}_{\text {year }}{ }^{-1}$ of $\mathrm{CH}_{4}$ is released from estuaries of Sundarbans to the regional atmosphere. The mean $\mathrm{CH}_{4}$ mixing ratio over the forest atmosphere was 2 ppmv. On annual basis, only $2.75 \%$ of total supplied $\mathrm{CH}_{4}$ to the forest atmosphere was transported to the upper atmosphere via biosphere-atmosphere exchange. Mean $\mathrm{CH}_{4}$ photo-oxidation rate over the forest atmosphere was $3.25 \times 10^{-9} \mathrm{mg} \mathrm{cm}^{-3} \mathrm{~d}^{-1}$. Using new and previously published data we present for the first time, a $\mathrm{CH}_{4}$ budget for Sundarbans mangrove ecosystem which in part, revealed the existence of anaerobic $\mathrm{CH}_{4}$ oxidation in the mangrove sediment column.

Keywords: methane, methanogenesis, methanotrophy, budget, mangrove, Sundarbans

\section{INTRODUCTION}

Methane $\left(\mathrm{CH}_{4}\right)$ is the key gas produced in anaerobic environments and represents the second most abundant greenhouse gas associated with climate change (Forster et al., 2007). Moreover, about $1 \%$ of the annually-fixed $\mathrm{CO}_{2}$ via photosynthesis is converted back to $\mathrm{CO}_{2}$ through microbial methanogenesis-with an estimated 1 billion tones of $\mathrm{CH}_{4}$ cycled this way each year (Rudolf and Seigo, 2006). The global atmospheric $\mathrm{CH}_{4}$ mixing ratio has increased from $722 \mathrm{ppbv}$ in the year 1,750 to $1,840 \mathrm{ppbv}$ in 2016 (http://cdiac.ornl.gov/pns/current_ghg.html; http://www.esrl. noaa.gov/gmd/ccgg/trends_ch4/). The cause of this large increase in atmospheric $\mathrm{CH}_{4}$ is not fully understood, but is probably related to a surge in $\mathrm{CH}_{4}$ emissions from wetlands that contribute approximately $20-39 \%$ of the annual global atmospheric $\mathrm{CH}_{4}$ budget (Hoehler and Alperin, 2014). Since $\mathrm{CH}_{4}$ is 26 times more effective than $\mathrm{CO}_{2}$ in its radiative forcing as a greenhouse gas 
(Lelieveld et al., 1993), we need to remain vigilent about the continually-evolving changes in the cycling of $\mathrm{CH}_{4}$ during the Anthropocene (Bridgham et al., 2013).

Mangroves are one of the most productive coastal environments, characterized by high turnover rates of organic matter and as well as exchange with the adjacent marine system (e.g., Donato et al., 2012; Alongi, 2014). Organic matter mineralization in sediments is a multi-step process that depends on the availability of oxygen and presence of terminal electron acceptors (TEAs). At the terminal step of organic matter decomposition, when all the TEAs have been consumed and electron donors are in surplus, $\mathrm{CH}_{4}$ is produced (requisite redox potential: $<150 \mathrm{mV}$; Wang et al., 1993) by a fermentative disproportionation reaction of low-molecular weight compounds (e.g., acetate), or by reduction of $\mathrm{CO}_{2}$ via hydrogen or simple alcohols (e.g., Canfield et al., 2005). In wetlands, sedimentary-derived $\mathrm{CH}_{4}$ can escape to the adjacent water/atmosphere via diffusive evasion, ebullition, and plantmediated transport (Chanton and Dacey, 1991). Past work has shown that diffusion is the least effective pathway (Chanton and Dacey, 1991; Laanbroek, 2010; Bridgham et al., 2013), with plant-mediation being the most globally-important source to the atmopshere from shallow-water ecosystems-which are largely freshwater and with emergent rooted plants (Bastviken et al., 2011). In coastal wetlands, the role of plant-mediated transport is significantly reduced because methanogenesis is largely suppressed by sulfate reduction. However, tidal effects can introduce another pathway of transport whereby during low-tide conditions, $\mathrm{CH}_{4}$-rich pore water is transported to adjacent creeks and estuaries through hypsometric gradients (Deborde et al., 2010; Santos et al., 2012; Stieglitz et al., 2013).

In estuarine water columns, $\mathrm{CH}_{4}$ can be partly oxidized to $\mathrm{CO}_{2}$ by methanotrophs (e.g., Hanson and Hanson, 1996), which reduces $\mathrm{CH}_{4}$ fluxes across water-atmosphere interface. In fact, for stratified lakes, methanotrophs can consume up to $90 \%$ of the dissolved $\mathrm{CH}_{4}$ (Utsumi et al., 1998; Kankaala et al., 2006). However, in well-mixed estuaries, the activity of methanotrophs has been shown to be significantly less, allowing for the possible escape of $\mathrm{CH}_{4}$ to the atmospshere (Abril et al., 2007). The amount of dissolved $\mathrm{CH}_{4}$ that escapes microbial oxidation in estuaries depends in large part on the $\mathrm{CH}_{4}$ concentration gradient at the air-water interface and the gas transfer velocity. The remaining $\mathrm{CH}_{4}$ can be exported to adjacent continental shelf regions where it only plays a very minor role in the larger global coastal carbon budget (Bauer et al., 2013). Once $\mathrm{CH}_{4}$ enters the atmosphere, across the sediment-atmosphere and water-atmosphere interfaces, there is enrichment of the atmospheric $\mathrm{CH}_{4}$ mixing ratio at a regional level. At this point, an entirely different set of complex atmospheric chemical transformations will determine its fate. Any emitted $\mathrm{CH}_{4}$ from mangroves will exchange across biosphere-atmosphere interface largely as a function of atmospheric turbulence. Another significant fraction of this emitted $\mathrm{CH}_{4}$ will undergo photo-oxidation-depending upon ambient $\mathrm{NO}_{\mathrm{x}}$ and $\mathrm{OH}$ radical concentrations (Wayne, 1991). Thus, the role of photo-oxidation of $\mathrm{CH}_{4}$ across the steep light gradients that exist in a mangrove forest canopy, which remain largely unknown, need to be considered when examining fluxes across the sediment-water-atmosphere continum. Finally, another interesting factor controlling the fate emitted $\mathrm{CH}_{4}$ in freshwater forested systems such as Cypress Swamps, is the role of plant-mediated $\mathrm{CH}_{4}$ efflux through cypress knees (composed of lenticels and aerenchyma tissue), where significant efflux of $\mathrm{CH}_{4}$ has been obeserved across the sediment-air interface (Bianchi et al., 1996).

The main objective of this study was to measure methanogenesis (in intertidal and sub-tidal sediments) and methanotrophy (in intertidal sediment) in the Indian Sundarbans, the largest tidal mangrove forest in the world. This builds on our previous work (Dutta et al., 2013, 2015a,b) only with more focus on the potential influences of sediment physicochemical parameters on pore-water $\mathrm{CH}_{4}$ distribution, the effects of pneumatophores and bioturbation density on the variability of sediment-atmosphere $\mathrm{CH}_{4}$ fluxes, and estuarine physicochemical parameters on $\mathrm{CH}_{4}$ oxidation. Perhaps more importantly, we present for the first time to our knowledge, a comprehensive quantitative $\mathrm{CH}_{4}$ budget for this globally-important wetland region.

\section{SAMPLING LOCATION}

The Sundarbans-located across India and Bangladesh at the land-ocean boundary of Ganges-Brahmaputra delta and the Bay of Bengal, is the largest single tidal mangrove forest in the world. This extensive natural mangrove forest has been established as a UNESCO world heritage site and covers an area of $10,200 \mathrm{~km}^{2}$, of which $4,200 \mathrm{~km}^{2}$ of reserved forest resides in India, with the remainder in Bangladesh. More specifically, the Indian Sundarbans Biosphere Reserve (SBR), which extends over an area of $9,600 \mathrm{~km}^{2}$, is comprised of $1,800 \mathrm{~km}^{2}$ of estuarine waterways and $3,600 \mathrm{~km}^{2}$ of reclaimed areas, in addition to the aforementioned mangrove reserve forest. The forest is about $140 \mathrm{~km}$ in length from east to west, and extends approximately $50-70 \mathrm{~km}$ from the southern margin of the Bay of Bengal toward the north.

The Indian Sundarban mangrove delta is fed by the sediment-rich waters of seven rivers, namely the Mooriganga, Saptamukhi, Thakuran, Matla, Bidya, Gosaba, and Haribhanga. These rivers form a sprawling archipelago of 102 islands, of which 54 have been reclaimed for human settlement with the others essentially uninhabited and relatively prisitine. Lothian Island, is one of these pristine islands situated at the buffer zone of the Sundarbans Biosphere Reserve-covering an area of $38 \mathrm{~km}^{2}$ (Figure 1). The island is completely intertidal and is occupied by thick, robust, and resilient mangrove trees, with a mean height of ca. $10 \mathrm{~m}$. The dominant species of mangroves are Avicennia alba, Avicennia marina, and Avicennia officinalis, with Excoecaria agallocha marginally distributed, and Ceriops decandra sparsley scattered across the island. The mangrove sediments are a silty clay largely composed of quartzo-feldspathic minerals such as quartz, albite, and microline (Ray et al., 2013). Lothian Island also 
borders the Saptamukhi River estuarine system (Figure 1), which has a mean depth $\sim 6 \mathrm{~m}$ (Dutta et al., 2015a) with no perennial source of freshwater, but receives significant amounts of agricultural and anthropogenic runoff-especially during monsoon season. Like entire Sundarbans, the regional climate of the study area is characterized by pre-monsoon (February-May), southwest monsoon (June-September), and northeast monsoon (or postmonsoon) (October-January) conditions. Although, Lothian Island, and its associated Saptamukhi estuary, represent only a small fraction of the larger Sundarbans mangrove ecosystem, we belive that the hydrologic, ecological, geological and climatic settings of the smaller sampling location is an ideal location for studying a subcomponent of $\mathrm{CH}_{4}$ cycling in the vast mangrove region.

\section{FIELD SAMPLING, FLUX MEASUREMENTS, AND ANALYTICAL METHODS}

\section{Field Sampling}

The present study was conducted during June 2010 to December 2012. Sediment and air samples were collected from intertidal mangrove sediments and a watch tower, located at the center of the Lothian Island $\left(21^{\circ} 42.58^{\prime} \mathrm{N}: 88^{\circ} 18^{\prime} \mathrm{E}\right)$, respectively (Figure 1). Water samples were collected in duplicate, on monthly basis from the Saptamukhi estuary along an estuarine stretch of $5 \mathrm{~km}$ (with $1 \mathrm{~km}$ intervals) near the Lothian Island jetty. Water temperature and $\mathrm{pH}$ were recorded in situ using a field thermometer and a portable $\mathrm{pH}$ meter (Orion Star A211), with a Ross combination electrode calibrated on the NBS (US National Bureau of Standards) scale (Frankignoulle and Borges, 2011). Reproducibility was $\pm 0.005 \mathrm{pH}$ units. Salinity and dissolved oxygen concentrations in surface and sub-surface waters were measured onboard, following the Mohr-Knudsen and Winkler titration methods, respectively (Grasshoff et al., 1983). Transparency of the water column was measured with a $15 \mathrm{~cm}$ diameter secchi disc. Water samples for dissolved inorganic nitrogen (DIN) analyses (e.g., nitrite, nitrate, and ammonia) were filtered in the field through Whatman GF/F filter paper, stored in HDPE bottles, and transported on ice to the laboratory.

\section{Flux Measurements}

Analysis of Sediment Samples and Flux Calculations across Sediment-Atmosphere and Sediment-Water

\section{Interfaces}

Intertidal sediment cores $(0-25 \mathrm{~cm}$ depth) were collected seasonally from different littoral zones (upper, mid, and lower) on the island using hand-held stainless-steel corers (diameter: $10 \mathrm{~cm}$ ). Estuarine bottom sediments (sub-tidal) were collected using grab samplers. All sediment samples were sealed in polythene bags and stored on ice during transport to the laboratory.

Cores were sliced in the laboratory (using a $\mathrm{N}_{2}$-filled glovebag) at the following $5 \mathrm{~cm}$ intervals: $0-5 ; 5-10 ; 10-15 ; 15-20$, and $20-25 \mathrm{~cm}$. Sediment redox potential $\left(\mathrm{E}_{\mathrm{h}}\right)$ was measured immediately using a platinum electrode and $\mathrm{Ag} / \mathrm{AgCl}$ reference electrode (Fiedler et al., 2003). Wet-sediment samples (both intertidal and sub-tidal) were processed for measurement of $\mathrm{CH}_{4}$ concentrations. Nitrite concentrations as well as sulfate, acidvolatile sulfide (AVS), and organic carbon percentages were also measured in sediments samples at all depth intervals (Dutta et al., 2013).

$\mathrm{CH}_{4}$ production rates of collected sediment samples (except $0-5 \mathrm{~cm}$ surface layer) were measured using anaerobic sediment incubations. Approximately $10 \mathrm{~g}$ of wet sediment were placed in an incubation bottle $(1.2 \mathrm{~cm}$ i.d. and $10 \mathrm{~cm}$ long) fitted with a teflon septum. The bottles were then flushed with high purity $\mathrm{N}_{2}$ for $1 \mathrm{~min}$. to create completely anaerobic conditions, and incubated in dark at a fixed ambient temperature (i.e., field temperature at that time) for $24 \mathrm{~h}$. At the end of the incubation, a $1 \mathrm{~mL}$ gas sample was withdrawn from the headspace through the rubber stopper using a gas-tight glass syringe (Lu et al., 1999). The collected gas sample was then analyzed for $\mathrm{CH}_{4}$ concentration, based on the purity of nitrogen as blank. $\mathrm{CH}_{4}$ production (in $\mu \mathrm{mol} \mathrm{CH}_{4} \mathrm{~m}^{-3}$ wet sediment $\mathrm{d}^{-1}$ ) was calculated based on $\mathrm{CH}_{4}$ enrichment in the headspace and volume of the sediment.

$\mathrm{CH}_{4}$ oxidation was measured for intertidal surface sediment following incubation of wet sediment $\left(\sim 6 \mathrm{~cm}^{3}\right)$ in a $60 \mathrm{~mL}$ rubber septum-fitted flask, with a headspace that was spiked with a $\mathrm{CH}_{4}$ standard (10.9 ppmv; procured from Chemtron Science Laboratories Pvt. Ltd.) (Saari et al., 1997). These flasks were then incubated at ambient temperature (i.e., field temperature) for 4 days in the dark. Gas samples from the headspace were drawn at the onset of incubation and over $24 \mathrm{~h}$ intervals until the termination of the experiment, and then analyzed for $\mathrm{CH}_{4}$ concentrations. $\mathrm{CH}_{4}$ oxidation was calculated by converting the loss of $\mathrm{CH}_{4}$ in the headspace with respect to volume of sediment.

During low tide conditions, $\mathrm{CH}_{4}$ emission rates from the intertidal sediment surface to the atmosphere, were measured using a static perspex chamber method (Purvaja et al., 2004; Dutta et al., 2015b). Basically, the chamber was placed in the sediment for a particular duration and $\mathrm{CH}_{4}$ emission rate was calculated based on the enrichment of the $\mathrm{CH}_{4}$ mixing ratio inside the chamber-relative to ambient air. Based on the precision of the air sample measurement method (discussed later), the minimum detectable flux using this chamber method would be $23.30 \mu \mathrm{mol} \mathrm{m} \mathrm{m}^{-2} \mathrm{~d}^{-1}$. Advective $\mathrm{CH}_{4}$ fluxes from intertidal forest sediment to the estuarine water column ( $\mathrm{F}_{\mathrm{ISW}}$ ) were computed according to the method used by Reay et al. (1995): $\mathrm{F}_{\mathrm{ISW}}=\Phi \times \nu \times \mathrm{C}$; where, $\Phi=$ porosity of sediment $=0.58$ (Dutta et al., 2013), $\nu=$ mean linear velocity $=\mathrm{d} \Phi^{-1}(\mathrm{~d}=$ specific discharge $), \mathrm{C}=$ pore water $\mathrm{CH}_{4}$ concentration in intertidal sediment. Porewater specific discharge was measured using a traditional, albeit rather "crude" method, which was based on the accumulation of pore water in an excavated pit of known surface area over time (Dutta et al., 2015a). This was performed during extreme low tide conditions on an intertidal flat at $100 \mathrm{~m}$ intervals during receding ebb flow. Diffusive $\mathrm{CH}_{4}$ fluxes were calculated using Fick's law of diffusion (e.g., Sansone and Graham, 2004). 


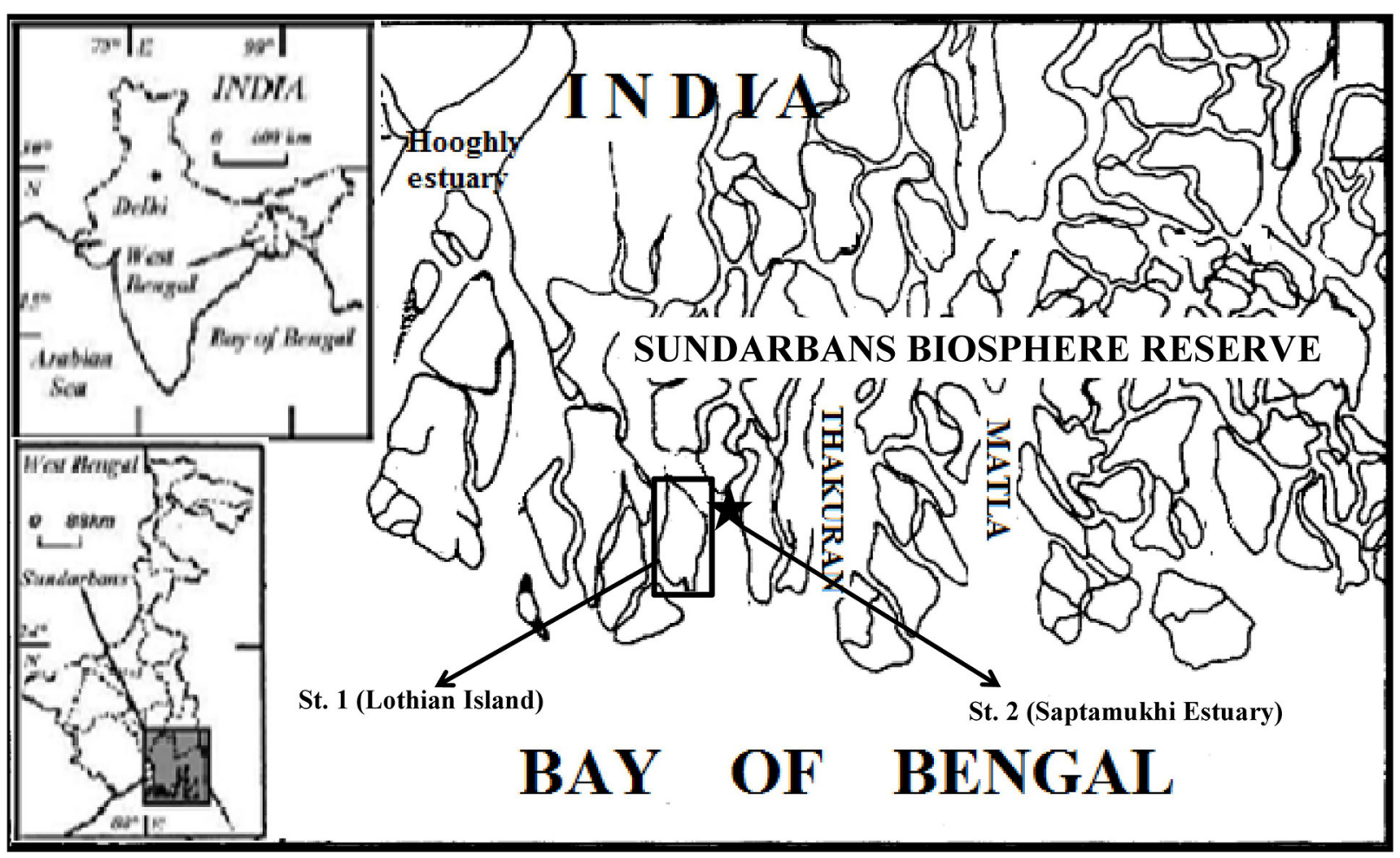

FIGURE 1 | Map showing locations of study area points where Lothian Island and its bordering Saptamukhi river estuary are presented with a sub-set.

\section{Analysis of Estuarine Water Samples and Water-Atmosphere $\mathrm{CH}_{4}$ Flux Calculation}

Collection and analysis of dissolved $\mathrm{CH}_{4}$ concentration and $\mathrm{CH}_{4}$ oxidation rates, in the Saptamukhi River estuarine waters, were performed according to the methods described by Dutta et al. (2013) and Dutta et al. (2015a), respectively; replicates were found to be within $2.30-3.14 \%$. $\mathrm{CH}_{4}$ fluxes across the air-water interface were calculated based on the wind speed parametization of the gas transfer velocity $(\mathrm{k})$, using the following expression: $\left.\mathrm{F}_{\mathrm{WA}}=\mathrm{k}\left[\mathrm{CH}_{4}\right]_{\text {observed }}-\left[\mathrm{CH}_{4}\right]_{\text {equilibrium }}\right]$ (Liss and Merlivat, 1986). Although, water current speed can play a significant role in generating water-side turbulence (and therefore " $k$ "), as recently reported by Ho et al. (2016), we were not able to include this parameter. A positive value denotes flux from water to the atmosphere and vice versa.

\section{Analysis of Atmospheric Samples, Micrometeorology,} and Biosphere-Atmosphere Flux Calculation

Samples for measurement of atmospheric $\mathrm{CH}_{4}$ mixing ratios were collected on monthly basis using an air sampling bulb, at heights of 10 and $20 \mathrm{~m}$ above the forest floor of Lothian Island, and then transported to laboratory for analysis. Two reference gas standards (10.9 and 5 ppmv, procured from Chemtron Science Laboratories Pvt. Ltd.) were run before and after every measurement to check for instrument. Duplicate samples were analyzed periodically and the replicate measurements were found to be within $2-3.2 \%$. Throughout the observation period the measured mixing ratios were corrected for water vapor. Meteorological parameters like air temperature and wind velocity were simultaneously recorded at 10 and $20 \mathrm{~m}$ heights above the forest floor of the island using a portable weather station (Model: Davis 7440). Mangrove biosphere-atmosphere $\mathrm{CH}_{4}$ exchange fluxes $\left(\mathrm{F}_{\mathrm{BA}}\right)$ were calculated using the following micrometeorological relationship (Barrett, 1998; Ganguly et al., 2008):

$$
\mathrm{F}_{\mathrm{BA}}=\mathrm{V}_{\mathrm{C}} \Delta \mathrm{x}
$$

where, $\Delta \chi=$ difference of $\mathrm{CH}_{4}$ mixing ratio between 10 and $20 \mathrm{~m}$ heights, and $\mathrm{V}_{\mathrm{C}}=$ exchange velocity $=1 /\left(\mathrm{r}_{\mathrm{a}}+\mathrm{r}_{\mathrm{s}}\right)\left(\mathrm{r}_{\mathrm{a}}\right.$ $=$ aerodynamic resistance and $r_{\mathrm{s}}=$ surface layer resistance). Negative flux values indicate influx from the atmosphere to the biosphere, while positive flux indicates an efflux emission from the biophere.

The aerodynamic resistance $\left(r_{a}\right)$ was calculated as follows (Wesely and Hicks, 1977):

$$
\mathrm{r}_{\mathrm{a}}=\left\{\ln \left(\mathrm{Z} / \mathrm{Z}_{\mathrm{o}}\right)-\Psi_{\mathrm{c}}\right\} / \mathrm{ku}^{*}
$$

where, $Z_{\mathrm{o}}$ is the roughness height, $\Psi_{\mathrm{c}}$ is a correction function for atmospheric stability. $\Psi_{\mathrm{c}}$ was computed as follows (Wesely and Hicks, 1977):

Stable condition: $\Psi_{\mathrm{c}}=-5(\mathrm{Z} / \mathrm{L})$ when $0<\mathrm{Z} / \mathrm{L}<1(\mathrm{Z}$ $=$ height and $\mathrm{L}=$ Obukhov scale length, $\mathrm{Z} / \mathrm{L}=$ atmospheric stability parameter). 
Unstable condition: $\Psi_{\mathrm{c}}=\exp [0.0598+0.39 \ln (-\mathrm{Z} / \mathrm{L})$ $\left.-0.09\{\ln (-\mathrm{Z} / \mathrm{L})\}^{2}\right]$ when $0>\mathrm{Z} / \mathrm{L}>-1$.

The friction velocity $\left(\mathrm{u}^{*}\right)$ was calculated as follows: $\mathrm{u}^{*}=\mathrm{k}\left(\mathrm{u}_{1}\right.$ $\left.-\mathrm{u}_{2}\right) / \ln \left(\mathrm{Z}_{2} / \mathrm{Z}_{1}\right)\left[\mathrm{k}\right.$ is the Von Karman constant, $\mathrm{u}_{2}$ and $\mathrm{u}_{1}$ are wind speeds at two heights, $Z_{2}$ and $Z_{1}$ ]

$Z_{0}$ was determined by plotting the wind profile as $\ln Z$ versus $\mathrm{u}$. The slope of the resulting straight line is $\mathrm{k} / \mathrm{u}^{*}$ and the intercept is $\ln Z_{\mathrm{o}}$. For forest cover, a displacement length (d) equal to $80 \%$ of the mean height of the roughness element (mean height of mangrove plant $=10 \mathrm{~m}$ ) was considered (Panofsky and Dutton, 1984). The scale length (L) was evaluated by the use of Pasquill stability classes A-F (Pruppacher and Klett, 1978) and is related to $Z_{o}$ (Golder, 1972) as: $1 / L=a+b \ln Z_{o}$, where " $a$ " ranges between 0.035 and -0.096 and " $b$ " ranges between 0.029 and -0.036 .

Surface layer resistance $\left(r_{s}\right)$ for forest cover was calculated as follows (Wesely and Hicks, 1977): $\mathrm{k} \mathrm{B}^{-1}=2\left(\mathrm{~K}_{\mathrm{D}} \mathrm{D}_{\mathrm{c}}\right)^{2 / 3} ; \mathrm{K}$ $=$ thermal diffusivity of air, $\mathrm{D}_{\mathrm{c}}=$ molecular diffusivity $=0.115$ $\left(\mathrm{T}_{2} / 273\right)^{1.5} ; \mathrm{T}_{2}=$ temperature at $20 \mathrm{~m}$ height and $\mathrm{B}^{-1}=$ transfer function.

$$
\mathrm{r}_{\mathrm{s}}=\mathrm{B}^{-1} / \mathrm{u}^{*}
$$

Drag coefficient $\left(C_{d}\right)$ at $10 \mathrm{~m}$ height was computed as: $C_{d}=r_{s} /(\rho$ $\left.\times \mathrm{V}_{102}\right) ; \rho=$ air density and $\mathrm{V}_{10}=$ wind velocity at $10 \mathrm{~m}$ height.

Sensible heat flux $(\mathrm{H})$ was calculated as follows (Ganguly et al., 2008): $\mathrm{H}=\rho_{\mathrm{t}} \mathrm{C}_{\mathrm{p}}\left(\mathrm{T}_{10 \mathrm{~m}}-\mathrm{T}_{20 \mathrm{~m}}\right) /\left(\mathrm{r}_{\mathrm{a}}+\mathrm{r}_{\mathrm{s}}\right) ; \rho_{\mathrm{t}}$ and $\mathrm{C}_{\mathrm{p}}$ are density and specific heat of air, respectively.

Height (h) of planetary boundary layer (PBL) was computed as follows (Pal Arya, 2001): $\mathrm{h}=\left(0.25 \mathrm{u}^{*}\right) /|\mathrm{F}|$. $\mathrm{F}$ is the Coriolis parameters related to the rotational speed of the earth $(\Omega)$ and latitude $(\Phi)$ as $F=2 \Omega \sin \Phi$.

$\mathrm{CH}_{4}$ photo-oxidation rates $(\mathrm{P})$ in the lower forest atmosphere were calculated based on the reaction $\left(\mathrm{CH}_{4}+\mathrm{OH} \rightarrow \mathrm{CH}_{3}+\right.$ $\mathrm{H}_{2} \mathrm{O}$ ) and equation of $P=\mathrm{k}\left[\mathrm{CH}_{4}\right][\mathrm{OH}]$ (Dutta et al., 2015b), where, $k=$ rate constant of the reaction between $\mathrm{CH}_{4}$, and $\mathrm{OH}=$ $1.59 \times 10^{-20} \mathrm{~T}^{2.84} \exp (-978 / \mathrm{T}) \mathrm{cm}^{3}$ molecule ${ }^{-1} \mathrm{~s}^{-1}$ (Vaghjiani and Ravishankara, 1991), $\left[\mathrm{CH}_{4}\right]=$ mean of all $\mathrm{CH}_{4}$ mixing ratio measurements during the day time at $10 \mathrm{~m}$ height in the diurnal cycle, and $[\mathrm{OH}]=$ mean of all $\mathrm{OH}$ radical concentrations during the day time at $10 \mathrm{~m}$ height in the diurnal cycle in molecules $\mathrm{cm}^{-3}$. OH radical concentrations were computed using photolysis frequency of $\mathrm{O}_{3}\left(\mathrm{O}_{3}\right.$ mixing ratio in the mangrove forest atmosphere ranged between $14.66 \pm 1.88$ and $37.90 \pm 0.91$ ppbv; Dutta et al., 2015b), based on the empirical relation given by Ehhalt and Rohrer (2009).

\section{Analytical Measurements}

All $\mathrm{CH}_{4}$ concentrations were measured according to method described Knab et al. (2009)-whereby, measurement of headspace $\mathrm{CH}_{4}$ was performed using gas chromatograph (Varian CP3800 GC), fitted with chrompack capillary column (12.5 m $\times 0.53 \mathrm{~mm}$ ), and a flame ionization detector (FID); the relative uncertainty for measurments were $\pm 2.9 \%$.

Sulfate and acid-volatile sulfide (AVS) concentrations of sediment samples were analyzed using standard spectrophotometric methods (Mussa et al., 2009; Simpson, 2011). All DIN concentrations (nitrate, nitrite, and ammonia) were also measured using standard spectrophotometric method
(Grasshoff et al., 1983). Replicates were found to be within $2.34-3.15, \quad 2.07-3.69, \quad 1.83-2.74,3.11-3.87$, and 3.24-3.99, respectively, for sulfate, AVS, nitrite, nitrate, and ammonia estimations. Percentage organic carbon (\%OC) of dried sediment samples were estimated using a high temperature combustion technique (TOC analyzer, Shimadzu SSM-5000A), which had a mean relative uncertainty of $2.8 \%$ (Dutta et al., 2013).

\section{Statisical Methods}

All the statistical analyses were performed using Sigma Plot Statistical Software version 11. A simple $t$-test was used to test for significance acorss different seasons, while multiple regression analyses were used to identify key controlling factors for variability in pore water $\mathrm{CH}_{4}$ concentrations as well as sediment and water column $\mathrm{CH}_{4}$ oxidation.

\section{RESULTS AND DISCUSSION}

\section{Sediment Geochemistry in the Mangroves of Lothian Island}

Spatial patterns in sedimentary $\mathrm{CH}_{4}$ production in the mangrove links significantly with redox potential $\left(\mathrm{E}_{\mathrm{h}}\right)$. $E_{h}$ values of mangrove surface sediment varied between -119.8 and $-103.2 \mathrm{mV}$ having a mean of $-111.4 \pm 6.78 \mathrm{mV}$ (Figure 2). Mangrove sediment redox potential values decreased significantly with sediment depth-reaching a minimum at $25 \mathrm{~cm}$ (varied between -167.8 and $-221.4 \mathrm{mV}$, mean = $-186.7 \pm 24.6 \mathrm{mV}$ ). These negative redox potential values indicated strong reducing conditions in mangrove sediments; even the oxic surface was not easily detectable. These observed redox condidions, which are highly conducive for anearobic microbial metabolism favors significant production of biogenic trace gases such as $\mathrm{N}_{2} \mathrm{O}, \mathrm{CH}_{4}$, and $\mathrm{H}_{2} \mathrm{~S}$ in this mangrove system (Dutta et al., 2013). In contrast to the Sundarbans mangrove ecosystem, mangrove sediments of New Caledonia were found to have positive redox potential values, to a sediment depth of $30 \mathrm{~cm}$, with negative $\mathrm{E}_{\mathrm{h}}$ values only found in considerably deeper sediments (Deborde et al., 2015). Such extreme differences sediment redox potential across different mangrove systems can typically be attributed to the geological setting (sediment porosity, organic matter supply), ecological factors (floral and faunal activities), hydrologic regime (tidal inundation and flushing). Past work has shown that methanogensis typically occurs at a redox of $<-150 \mathrm{mV}$ (Wang et al., 1993) similar to values observed in Lothian Island sediments (at depth of $10-25 \mathrm{~cm}$ ), consistent with our previous work Dutta et al. (2013). Surface sediment $\mathrm{SO}_{4}^{2-}-\mathrm{S}$ concentrations ranged from 15.36 to $25.07 \mathrm{mM}$, with a mean of $20.54 \pm 4.89 \mathrm{mM}$ (Figure 3). The range of $\mathrm{SO}_{4}^{2-}-\mathrm{S}$ concentrations between sediment depths of $20-25 \mathrm{~cm}$ was $27.16-27.70 \mathrm{mM}$, were 1.34 times higher than surface sediment values. Once again, if we compare these $\mathrm{SO}_{4}^{2-}-\mathrm{S}$ concentrations to the mangrove system in New Caladonia, they are considerably lower (Deborde et al., 2015). One other difference was that in the Lothian Island Sundarbans sediment, $\mathrm{SO}_{4}^{2-}-\mathrm{S}$ concentrations had a significant decrease only within upper $15 \mathrm{~cm}$ depth of sub-surface mangrove sediment consistent 


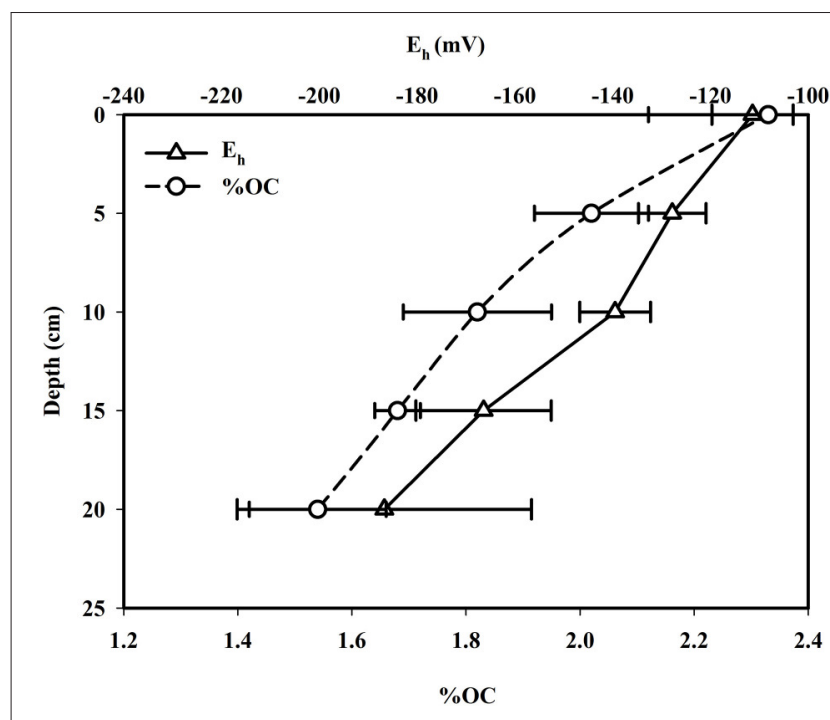

FIGURE 2 | Vertical distributions of $E_{h}$ and percent $O C$ in mangrove sediment.

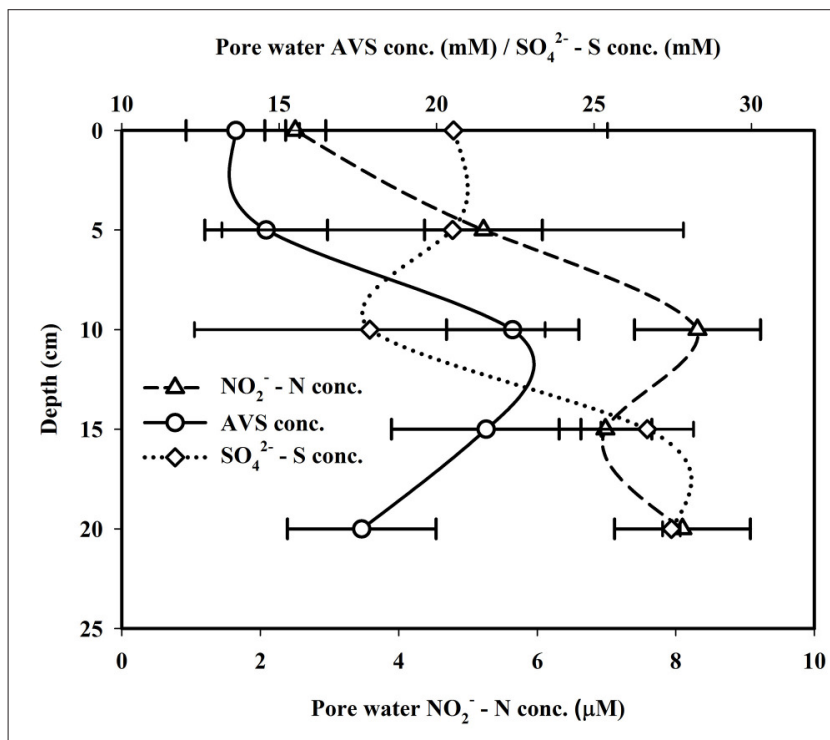

FIGURE 3 | Vertical distributions of pore water $\mathrm{NO}_{2}^{-}-\mathrm{N}, \mathrm{SO}_{4}^{2-}-\mathrm{S}$, and AVS concentrations in mangrove sediment.

with patterns of peak sulfate reduction, with methanogenesis occurring deeper in the sediments (more discussion on this later).

AVS concentrations in the Lothian Island Sundarbans sediment varied between 13.32 and $13.95 \mathrm{mM}$ with a mean of $13.63 \pm 0.32 \mathrm{mM}$ (Figure 3 ). In contrast to sulfate profiles, downcore AVS concentrations showed distinctly higher values within the $10-15 \mathrm{~cm}$ region of the sediment profile. Mangrove surface sediment $\mathrm{NO}_{2}^{-}-\mathrm{N}$ concentrations varied between 1.61 and $4.14 \mu \mathrm{M}$, with a mean of $2.51 \pm 1.41 \mu \mathrm{M}$. However, downcore $\mathrm{NO}_{2}^{-}-\mathrm{N}$ concentrations reached a maximum between 10 and $15 \mathrm{~cm}$ depth in sediments (varied between 1.99 and
$18.53 \mu \mathrm{M})$, possibly indicating the dominance of denitrifying bacterial activity at that depth (Figure 3). Percent $\mathrm{OC}$ in mangrove surface sediments on Lothian Island varied between 2.1 and 2.51, with a mean of $2.33 \pm 0.21$ (Figure 2), and decreased in concentration by $\sim 34 \%$ at sediments depths of $20-$ $25 \mathrm{~cm}$, where concentrations varied between 1.41 and $1.63 \%$. The $\% \mathrm{OC}$ measured here was lower than values previously reported by Jennerjahn and Ittekkot (1997) for the mangrove area in the Paraiba do Sul river mouth (4.82\%). However, they were within the range of those reported by Bouillon et al. (2004) for mangroves located near Godavari estuary (0.6-31.7\%), near the Indian and southwest coast of Srilanka. The decreasing trend of \%OC coupled with decreasing redox potential across deep mangrove sediment indicates significant OC mineralization by anaerobic microbial respiration.

\section{$\mathrm{CH}_{4}$ Production Rates in Sediment}

While only marginal $\mathrm{CH}_{4}$ production $\left(215-1,176 \mu \mathrm{mol} \mathrm{CH}_{4}\right.$ $\mathrm{m}^{-3}$ wet sediment $\mathrm{d}^{-1}$ ) was observed in sediments between 5 to $10 \mathrm{~cm}$ in depth, a significant $[p(=0.02)<0.05]$ increase (2,089 to $4,033 \mu \mathrm{mol} \mathrm{CH} \mathrm{CH}^{-3}$ wet sediment $\left.\mathrm{d}^{-1}\right)$ was observed at sediment depths of 10 to $15 \mathrm{~cm}$ (Figure 4). This trend of increasing $\mathrm{CH}_{4}$ production rates with sediment depth continued even deeper in mangrove sediments with increases between 2,919 to 5,903 and 4,290 to $7,353 \mu \mathrm{mol} \mathrm{CH}_{4} \mathrm{~m}^{-3}$ wet sediment $\mathrm{d}^{-1}$, respectively, for depth of 15 to $20 \mathrm{~cm}[p(=0.32)>0.05]$ and 20 to $25 \mathrm{~cm}[p(=0.31)>0.05]$. The depthwise (D) variability of $\mathrm{CH}_{4}$ production rates $\left(\left[\mathrm{CH}_{4}\right]_{\mathrm{PI}}\right)$ in the intertidal sediment column was examined using the following logarimetric equation:

$$
\left[\mathrm{CH}_{4}\right]_{\mathrm{PI}}=3547 \ln \mathrm{D}-5045\left(\mathrm{R}^{2}=0.99\right)
$$

The production rates measured for this study site varied between 215 and $7,353 \mu \mathrm{mol} \mathrm{CH} \mathrm{m}^{-3}$ wet sediment $\mathrm{d}^{-1}$, mean $=3,547$ $\pm 2,205 \mu \mathrm{mol} \mathrm{CH} \mathrm{Cm}^{-3}$ wet sediment $\mathrm{d}^{-1}$, and were within the range reported for pristine mangrove forests at Balandra, Mexico (Strangmann et al., 2008). While we did not measure $\mathrm{CH}_{4}$ in the upper 0 to $5 \mathrm{~cm}$ in this study, due to the low methanogenic and intense methanotrophic activities in that layer, these rates are likely an underestimate-but were still quite high. However, in the bordering Saptamukhi estuarine system near our study site, $\mathrm{CH}_{4}$ production rate in the top $5 \mathrm{~cm}$ of sub-tidal sediment varied between 18.72 and $85.74 \mu \mathrm{mol} \mathrm{CH}_{4} \mathrm{~m}^{-3}$ wet sediment $\mathrm{d}^{-1}$, with a mean of $48.88 \pm 26.04 \mu \mathrm{mol} \mathrm{CH}_{4} \mathrm{~m}^{-3}$ wet sediment $\mathrm{d}^{-1}$.

Seasonally, mangrove sediment $\mathrm{CH}_{4}$ production rates were higher $[p(=0.21)>0.05]$ in post-monsoon $(4,616 \pm 2,666 \mu \mathrm{mol}$ $\mathrm{CH}_{4} \mathrm{~m}^{-3}$ wet sediment $\left.\mathrm{d}^{-1}\right)$ compared to pre-monsoon $(2,378$ $\pm 1,799 \mu \mathrm{mol} \mathrm{CH}_{4} \mathrm{~m}^{-3}$ wet sediment $\mathrm{d}^{-1}$ ) seasons. The higher post-monsoon $\mathrm{CH}_{4}$ production rate may be attributed to the presence of high mangrove leaf litter-fall at this time (58.79 $\mathrm{g}$ dry wt $\mathrm{C} \mathrm{m}^{-2}$ month $^{-1}$; Ray et al., 2011), which likely mediated by the supply of labile organic matter in these sediments- supporting higher $\mathrm{CH}_{4}$ production. In contrast, higher salinity conditions during pre-monsoon may have partially inhibited sediment $\mathrm{CH}_{4}$ production rate. For example, Marton et al. (2012) also reported lower $\mathrm{CH}_{4}$ production rates during high salinity conditions. Other work in tidal mangrove forests have shown that intrusion 


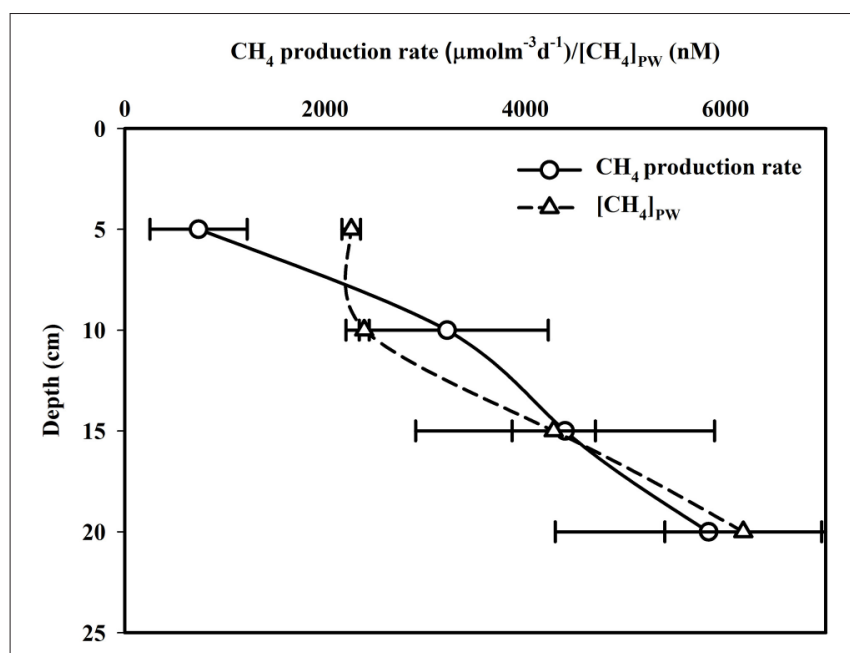

FIGURE 4 | Vertical distributions of $\mathrm{CH}_{4}$ production rates and pore water $\mathrm{CH}_{4}$ concentrations at intertidal mangrove sediment.

of high salinity waters results in higher pore-water salinities, along with availibility of terminnal electron acceptors (e.g., $\mathrm{NO}_{3}^{-}$, $\mathrm{SO}_{4}^{2-}$ )-which constrain $\mathrm{CH}_{4}$ production (Craft et al., 2009; Larsen et al., 2010).

Sub-tidal sediment in post-monsoon season had significantly $[p(=0.03)<0.05]$ higher $\mathrm{CH}_{4}$ production rates $(77.06$ $\pm 12.27 \mu \mathrm{mol} \mathrm{CH}_{4} \mathrm{~m}^{-3}$ wet sediment $\mathrm{d}^{-1}$ ) compared to pre-monsoon conditions $\left(21.28 \pm 3.63 \mu \mathrm{mol} \mathrm{CH}_{4} \mathrm{~m}^{-3}\right.$ wet sediment $\left.\mathrm{d}^{-1}\right)$. These was a $\sim 35.25 \%$ higher OC supply to the sub-tidal sediment surface during post-monsoon $(2.21 \pm$ $0.69 \%)$ compared to pre-monsoon $(1.56 \pm 0.72 \%)$, which likely contributed to the observed oxygen draw-down which favored higher $\mathrm{CH}_{4}$ production.

\section{Utilization of Organic Carbon and Linkages to Methanogenesis}

Methanogens can only utilize a limited number of substrates and with the major pathways being (I) fermentation of acetate, commonly referred to as acetoclastic methanogenesis (AM) (Equation 1), and (II) acetate oxidation (Equation 2), where $\mathrm{CO}_{2}$ is reduced with $\mathrm{H}_{2}$ (hydrogenotrophic methanogenesis [HM]) (Equation 3) (Zinder, 1993; Mayumi et al., 2013). The aforementioned equations are shown below:

$$
\begin{aligned}
\mathrm{CH}_{3} \mathrm{COO}^{-}+\mathrm{H}^{+} & =\mathrm{CH}_{4}+\mathrm{CO}_{2} \\
\mathrm{CH}_{3} \mathrm{COO}^{-}+\mathrm{H}^{+}+2 \mathrm{H}_{2} \mathrm{O} & =4 \mathrm{H}_{2}+2 \mathrm{CO}_{2} \\
4 \mathrm{H}_{2}+\mathrm{CO}_{2} & =\mathrm{CH}_{4}+2 \mathrm{H}_{2} \mathrm{O}
\end{aligned}
$$

Mayumi et al. (2013) calculated change in Gibbs free energy $\left(\Delta \mathrm{G}^{\circ}\right)$ values for the aforementioned reactions in well-controlled $\mathrm{CO}_{2}$-injected microcosms. This work showed that acetate oxidation, under these microcosm conditions, was endergonicindicating a predominance of $\mathrm{AM}$ over the $\mathrm{HM}$ in a $\mathrm{CO}_{2}$ rich environment. Moreover, Lessner (2009) reported that $~ 70 \%$ of biologically-produced $\mathrm{CH}_{4}$ originated from the conversion of the methyl group of acetate to $\mathrm{CH}_{4}$. Thus, considering the $\mathrm{CO}_{2}$-rich character of the Sundarban mangrove environment (Biswas et al., 2004), we speculate that AM likely predominated in these sediments. If we make this assumption, the stoichiometric equation of acetoclastic methanogenesis (Equation 1) would require the utilization of 2 moles of OC per mole of $\mathrm{CH}_{4}$ production. Along with production of $\mathrm{CH}_{4}$, the reaction also produces one mole of $\mathrm{CO}_{2}$ as by-product. Using the above equations, we calculated that in the intertidal sediment (from 0 to $25 \mathrm{~cm}$ depth), $4,966 \mu \mathrm{mol} \mathrm{m} \mathrm{m}^{-3} \mathrm{~d}^{-1}$ of OC was transformed through an AM pathway producing both $\mathrm{CH}_{4}$ and $\mathrm{CO}_{2}$ as $2,483 \mu \mathrm{mol} \mathrm{m} \mathrm{m}^{-3} \mathrm{~d}^{-1}$. Similarly in the estuarine bottom sediment, adjacent to the island, $68.33 \mu \mathrm{mol} \mathrm{m} \mathrm{m}^{-3} \mathrm{~d}^{-1}$ of OC was transformed through the AM pathway producing $34.22 \mu \mathrm{mol}$ $\mathrm{m}^{-3} \mathrm{~d}^{-1}$ of $\mathrm{CH}_{4}$ and $34.22 \mu \mathrm{mol} \mathrm{m}^{-3} \mathrm{~d}^{-1}$ of $\mathrm{CO}_{2}$. The release of $\mathrm{CH}_{4}$, and $\mathrm{CO}_{2}$ as by-products, possibly enhancing potential regional effects on climate change. However, mangroves are also well-known to be blue carbon habitats, which sequester and store $\mathrm{CO}_{2}$ (Bouillon et al., 2008; Alongi, 2012). Thus, further work is needed to establish the overall role of these mangroves as net sinks or sources of greenhouse gases. Finally, although we did not examine the role of sulfate reduction in this study, based on the relatively low \%OC in these mangrove sediments (Prasad et al., 2017), it is likely to be another very important anaerobic process for sedimentary OC processing in the Sundarbans mangrove ecoystem.

\section{Pore-Water $\mathrm{CH}_{4}$ Levels and its Fluxes to the Adjacent Saptamukhi River Estuary}

Pore-water $\mathrm{CH}_{4}$ concentrations in intertidal mangrove sediments of Lothian Island were relatively constant within the 10 to $15 \mathrm{~cm}$ sediment layers (varied between 1,881 and $2,429 \mathrm{nM})$, and then abruptly $[p(=0.001)<0.05]$ increased to concentrations of 3,804 and $4,542 \mathrm{nM}$ between 15 and $20 \mathrm{~cm}$ with further significant increases $[p(=0.02)<0.05]$ to 5,274 and $6,670 \mathrm{nM}$ between 20 and $25 \mathrm{~cm}$ (Figure 4). On seasonal basis, mean pore-water $\mathrm{CH}_{4}$ concentrations in intertidal sediments were higher $[p(=0.69)>0.05]$ in post-monsoon $(3,639 \pm$ $1,949 \mathrm{nM})$ compared to pre-monsoon season $(3,204 \pm 1,325 \mathrm{nM})$ (Dutta et al., 2015a). Considering pore-water $\mathrm{CH}_{4}$ concentration $\left(\left[\mathrm{CH}_{4}\right]_{\mathrm{PW}}\right)$ as a dependent variable relative to other independent parameters measured $\left(\mathrm{E}_{\mathrm{h}},\left[\mathrm{NO}_{2}^{-}-\mathrm{N}\right],\left[\mathrm{SO}_{4}^{2-}-\mathrm{S}\right],[\mathrm{AVS}]\right.$ and $\% \mathrm{OC})$, a multiple regression analysis $\left(\left[\mathrm{CH}_{4}\right]_{\mathrm{PW}}=0.03-\right.$ $0.0308 \mathrm{E}_{\mathrm{h}}-1.08[\% \mathrm{OC}]+0.0691\left[\mathrm{SO}_{4}^{2-}-\mathrm{S}\right]-0.0459[\mathrm{AVS}]$ $+0.0034\left[\mathrm{NO}_{2}^{-}-\mathrm{N}\right] ; R^{2}=93.1 \%, F=21.71, p<0.001$, $n=28)$ revealed a significant correlation between $\left[\mathrm{CH}_{4}\right]_{\mathrm{PW}}$ and $E_{h}(p=0.017)$ - but not with others. This suggests the potential impact of sediment redox potential on the variability of mangrove sediment pore-water $\mathrm{CH}_{4}$ concentrations. Mean sub-tidal sediment pore-water $\mathrm{CH}_{4}$ concentrations were significantly higher in pre-monsoon $(3,980 \pm 1,227 \mathrm{nM})$ than in post-monsoon conditions $(2,770 \pm 1,039 \mathrm{nM})$ (Dutta et al., 2015a), which followed a similar seasonal trend for intertidal sediments. Overall, sediment pore waters in the intertidal mangrove sediments of Lothian Island were ca. 53.4 times more supersaturated than the adjacent estuarine sediments. This 
clearly indicates a significant source $\mathrm{CH}_{4}$ to the estuarine $\mathrm{CH}_{4}$ sediment pool, via advective (ranged between $115.81 \pm 31.02$ and $199.15 \pm 47.89 \mu \mathrm{mol} \mathrm{m} \mathrm{m}^{-2} \mathrm{~d}^{-1}$; Figure 5) and diffusive fluxes (ranged between $7.06 \pm 1.95$ and $10.26 \pm 2.43 \mu \mathrm{mol} \mathrm{m}^{-2}$ $\mathrm{d}^{1}$; Figure 6) (Dutta et al., 2015a). Unfortunately, to the best of our knowledge no estimates have been made on advective $\mathrm{CH}_{4}$ fluxes from intertidal mangrove to Saptamukhi River estuarine system. It should be noted that these are the the first reported measurments of advective $\mathrm{CH}_{4}$ fluxes from Indian Sundarbans, albeit using a traditional rather "crude" method. Although, our estimated pore water specific discharge rates $\left(3.60-5.76 \mathrm{~cm} \mathrm{~d}^{-1}\right)$ were in the range of that measured for other mangrove regions located at temperate and tropical regions $\left(2.10-35.50 \mathrm{~cm} \mathrm{~d}^{-1}\right.$; Tait et al., 2016) by combined natural tracer Radon $\left({ }^{222} \mathrm{Rn}\right)$ with hydrodynamic models but as such, more accurate measurements are needed in near future to better constrain such measurements in the this globally-important ecosystem.

When compared to a temperate system, diffusive $\mathrm{CH}_{4}$ fluxes from sub-tidal sediment of the Saptamukhi estuary were comparable to those found in the Arcachon tidal lagoon (France) $\left(11.97 \mu \mathrm{mol} \mathrm{m}{ }^{-2} \mathrm{~d}^{-1}\right.$; Deborde et al., 2010). Similarly, our diffusive $\mathrm{CH}_{4}$ fluxes were also higher than in the Yangtze temperate estuary, China $\left(1.7-2.2 \mu \mathrm{mol} \mathrm{m} \mathrm{m}^{-2}\right.$

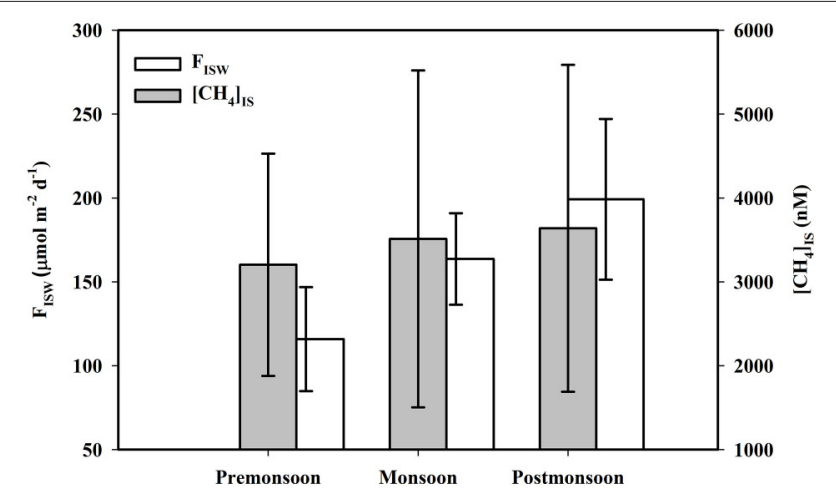

FIGURE 5 | Seasonal variations of mangrove sediment pore water $\mathrm{CH}_{4}$ concentration $\left(\left[\mathrm{CH}_{4}\right]_{\mid S}\right)$ and its advective flux to estuary ( $\left.\mathrm{F}_{\mathrm{ISW}}\right)$

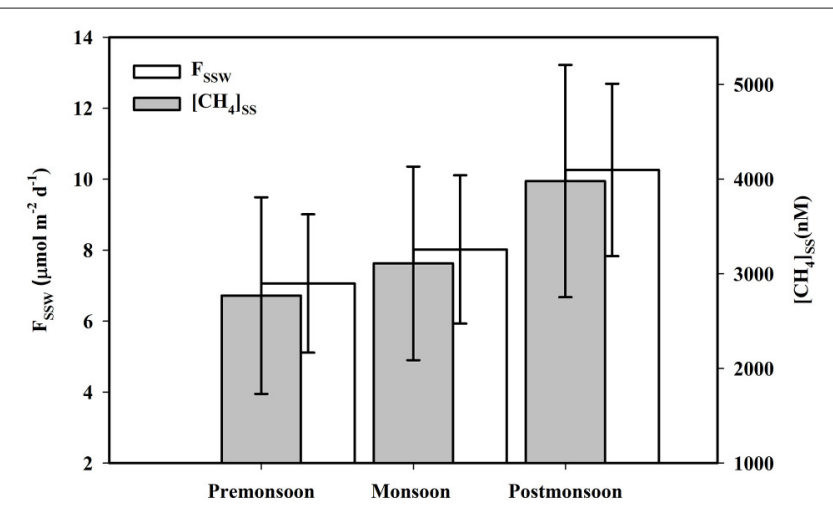

FIGURE 6 | Seasonal variations of sub-tidal sediment pore water $\mathrm{CH}_{4}$ concentration ( $\left.\left[\mathrm{CH}_{4}\right]_{S S}\right)$ and its diffusive flux to estuary ( $\mathrm{FSSW}_{\mathrm{SW}}$ ). $\mathrm{d}^{-1}$; Zhang et al., 2008), yet lower than White Oak river estuary, in northern California $\left(17.1 \mu \mathrm{mol} \mathrm{m} \mathrm{m}^{-2} \mathrm{~d}^{-1}\right.$; Kelley et al., 1990). While such cross-system comparisons are frought with the complexity of regional differences in ecological and physicochemical drivers of fluxes, we provide them for a simple geographic perspective here. Nevertheless, we can conclude that in the Indian Sundarbans fluxes measured during post-monsoon period were higher compared to premonsoon conditions, but were only significant for advective fluxes $[p(=0.0006)<0.05]-$ not for diffusive fluxes $[p(=$ $0.21)>0.05]$. The peak post-monsoon advective $\mathrm{CH}_{4}$ flux may be due to maximal intertidal sediment pore water $\mathrm{CH}_{4}$ concentrations, as well as pore water specific discharge $(5.76 \mathrm{~cm}$ $\mathrm{d}^{-1}$ ). Peak diffusive $\mathrm{CH}_{4}$ flux may be attributed to maximal subtidal sediment pore water $\mathrm{CH}_{4}$ concentrations, which resulted in a greater $\mathrm{CH}_{4}$ concentration gradient at sediment-water interface.

\section{$\mathrm{CH}_{4}$ Oxidation and Emission at/from Mangrove Surface Sediment}

Mean surface sediment $\mathrm{CH}_{4}$ oxidation rates $(1.76 \pm 0.34 \mathrm{mg}$ $\mathrm{m}^{-2} \mathrm{~d}^{-1}$ ) measured in the Lothian Island mangrove forest were within the range of that reported by Bradford et al. (2001) and Jang et al. (2006). The mean peak pre-monsoon $\mathrm{CH}_{4}$ oxidation rate $\left(2.149 \pm 0.16 \mathrm{mg} \mathrm{m}^{-2} \mathrm{~d}^{-1}\right.$; Figure 7$)$ are likely linked with maximum soil surface temperatures. Seasonal $\mathrm{CH}_{4}$ exchange across mangrove sediment-atmosphere interface in Lothian Island mangroves revealed an annual mean flux of 452 $\pm 126 \mu \mathrm{mol} \mathrm{m} \mathrm{m}^{-2} \mathrm{~d}^{-1}$ (Figure 7), indicative of a net source of $\mathrm{CH}_{4}$ from mangrove sediments to the atmosphere. These fluxes were within the range of those reported by Purvaja et al. (2004) in the Pichavaram mangrove, located at the northern end of the Cauvery delta, India, and along the coast of Puerto Rico (Sotomayor et al., 1994). Soil temperatures and salitinties have been show to have a significant impact on $\mathrm{CH}_{4}$ emissions $\left(\mathrm{F}_{\mathrm{SA}}\right)$ from mangroves (Bartlett et al., 1987; Lekphet et al., 2005). Lothian Island mangroves soil temperature and pore water salinity ranged between $18.25 \pm 0.22$ and $28.36 \pm 1.02^{\circ} \mathrm{C}(\mathrm{t})$ and $22.55 \pm 0.31$ and $28.88 \pm 0.13$ (s), respectively. Both soil temperature and salinity were maximal during pre-monsoon and minimal during post-monsoon seasons, respectively. "FS" was best fitted linearly with " $\mathrm{t}$ " $\left(R^{2}=0.35, F=5.33, p=0.041\right.$, $n=12$ ), however, a second order polynomial relationship with "s" $\left(R^{2}=0.77, F=7.71, p=0.029, n=12\right)$, indicated a cumulative effect of temperature and salinity on variability of sediment $\mathrm{CH}_{4}$ emission fluxes. A similar effect was previously reported in Ranong Province mangrove area, Thailand (Lekphet et al., 2005) and in a salt marsh at Queen's creek (Bartlett et al., 1987).

In Lothian Island mangroves, we observed higher spatial variability on $\mathrm{CH}_{4}$ emissions $\left(432-761 \mu \mathrm{mol} \mathrm{m} \mathrm{m}^{-2} \mathrm{~d}^{-1}\right)$ in the upper littoral zone compared to mid and lower littoral zones. This was likely due to the higher pneumatophore density in that region ( 42 number $\mathrm{m}^{-2}$ ) and the associated plant-mediated diffusion of $\mathrm{CH}_{4}$ through them (Dutta et al., 2013). This further supports the role of plant-mediated transport of $\mathrm{CH}_{4}$ across the sediment atmosphere interface in aquatic system (Chanton 


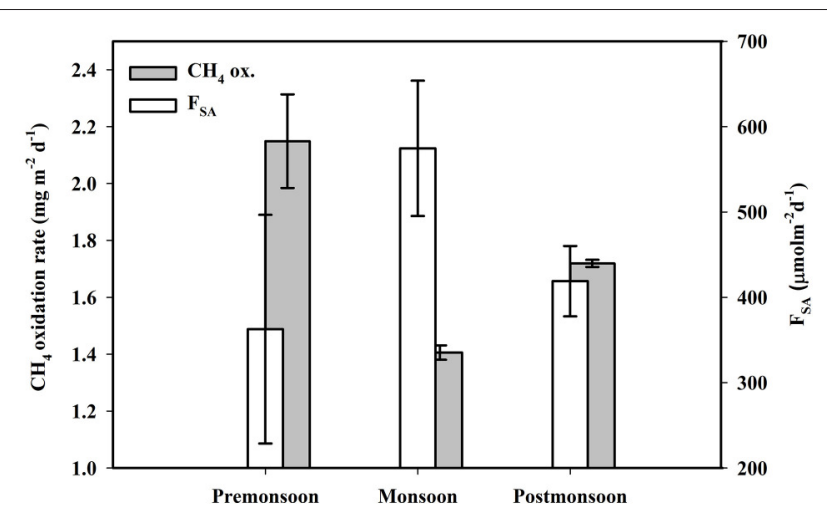

FIGURE 7 | Seasonal variations of mangrove surface sediment $\mathrm{CH}_{4}$ oxidation and $\mathrm{CH}_{4}$ emission ( $\mathrm{F}_{\mathrm{SA}}$ ) across mangrove sediment-atmosphere interface of Lothian Island.

and Dacey, 1991; Laanbroek, 2010; Bridgham et al., 2013). In fact, a significant correlation was found between " $F_{S A}$ " with both pneumatophore $\left(\mathrm{P}_{\text {no }}\right)$ and bioturbation $\left(\mathrm{B}_{\mathrm{o}}\right)$ densities, with positive correlation with pneumatophore $\left(\mathrm{F}_{\mathrm{SA}}=400.13+0.56\right.$ $\left.\mathrm{P}_{\text {no }} ; R^{2}=81.9 \%, F=6.94, p=0.032, n=20\right)$ and negative with bioturbation $\left(\mathrm{F}_{\mathrm{SA}}=444.38-0.028 \mathrm{~B}_{\mathrm{no}} ; R^{2}=61.9 \%, F=\right.$ 5.94, $p=0.041, n=20)$. The positive correlation between sediment $\mathrm{CH}_{4}$ emission flux with pneumatophore density via plant-mediation, and negative correlation via bioturbation e.g., burrowing crabs (Kristensen and Alongi, 2006), reflect the complex and changing dynamics of plant-and-animal populations on intertidal sediment-atmosphere $\mathrm{CH}_{4}$ emission fluxes.

\section{Estuarine $\mathrm{CH}_{4}$ Biogeochemistry Physicochemical Properties of the Saptamukhi River Estuary}

Physicochemical parameters of the Saptamukhi River estuarine waters are presented on seasonal basis in Figures 8, 9. For both temperature and salinity, the values were highest during the pre-monsoon and lowest during the post-monsoon (for temperature) and monsoon (for salinity) months. The lack of variability between estuarine surface and sub-surface water temperature and salinity clearly indicated the presence of a well-mixed water column (Dutta et al., 2015a). Seasonal differences of $\mathrm{pH}$ were not significant and ranged between 8.10 \pm 0.03 and $8.17 \pm 0.16$. Dissolved oxygen (DO) concentrations in estuarine surface and sub-surface waters were high $(0.19$ \pm 0.023 to $0.23 \pm 0.036$ and $0.17 \pm 0.001$ to $0.19 \pm$ $0.025 \mathrm{mM}$, respectively; Figure 8), and DO \% of saturation ranged from 94.8 to 99.3 . These high oxygen values reflect a well-mixed oxygenated water column, that should restrain most anaerobic microbial metabolism of organic matter within estuarine water column. However, it should also be noted that $\mathrm{CH}_{4}$ production in the isolated anoxic microhabitats of sinking particulate organic matter (POM), in well-oxygenated water column, have been observed in the open ocean (see Reeburgh, 2007).

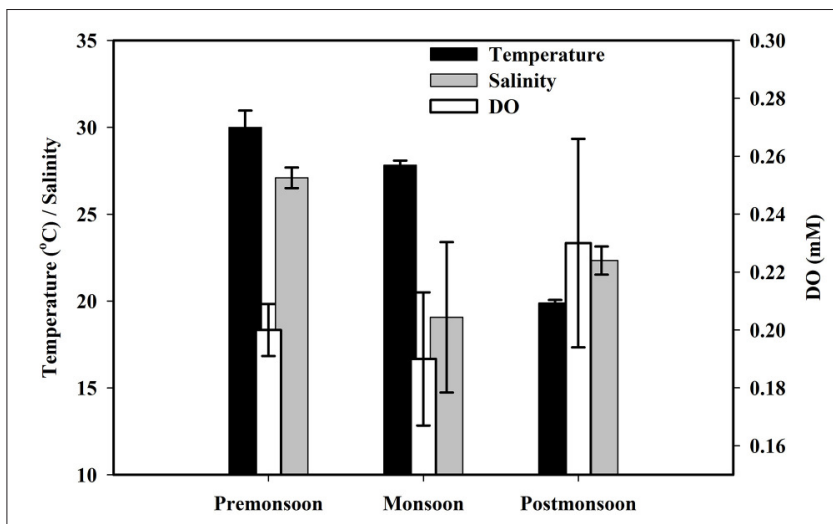

FIGURE 8 | Seasonal variations of estuarine surface water temperature, salinity, and DO conc.

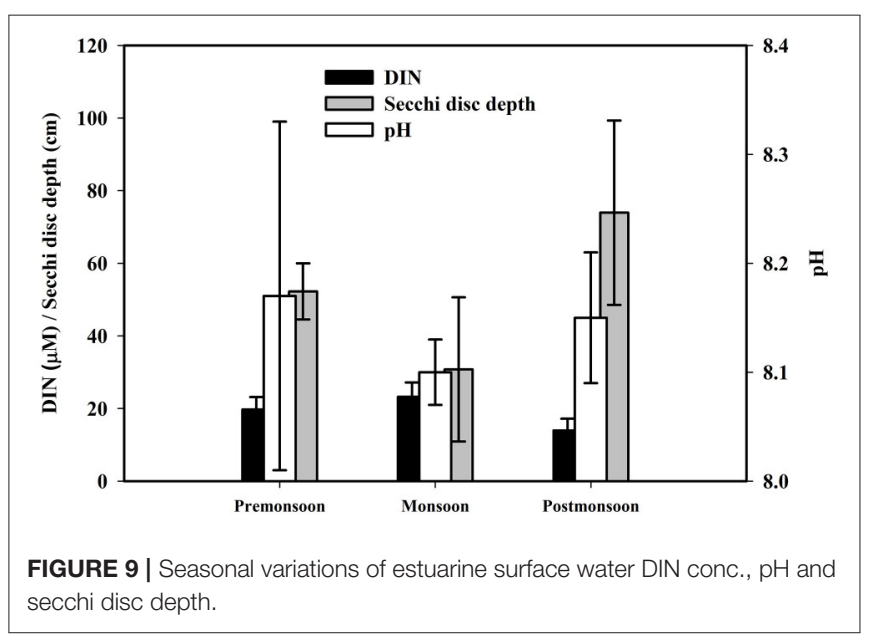

\section{Distribution of Dissolved $\mathrm{CH}_{4}$}

Previous studies have shown that $\mathrm{CH}_{4}$ concentrations of the Saptamukhi River estuarine surface and sub-surface waters ranged from $54.20 \pm 5.06$ to $90.91 \pm 21.20$ and $47.28 \pm$ 12.85 to $67.97 \pm 33.12 \mathrm{nM}$ (Table 1), respectively (Dutta et al., 2015a). The concentrations measured for this tropical mangrovedominated estuary (Figure 10) were within the range of that reported for other tropical estuaries located at west (113 \pm $40 \mathrm{nM})$ and east $(27 \pm 6 \mathrm{nM})$ coast of India, such as Luper (5.2$59 \mathrm{nM}$ ) and Saribus (3.7-135 nM), as well as estuaries located in northwestern Borneo (Muller et al., 2016; Rao and Sarma, 2016). Seasonally, estuarine surface water $\mathrm{CH}_{4}$ concentrations during post-monsoon $(90.91 \pm 21.20 \mathrm{nM})$ were significantly higher [ $p$ $(=0.01)<0.05]$ compared to pre-monsoon $(54.20 \pm 5.06 \mathrm{nM})$ conditions. This was likley due to the cumulative effects of maximum $\mathrm{CH}_{4}$-rich pore water influx from adjacent intertidal mangrove sediments to the estuary as well as minimal $\mathrm{CH}_{4}$ oxidation (will be discussed later) within these estuarine waters during post-monsoon conditions. Estuarine $\mathrm{CH}_{4}$ concentrations showed a significantly negative correlation with salinity (premonsoon: $R^{2}=89.1 \%, F=49.15, p<0.001, n=$ 8; monsoon: $R^{2}=95.2 \%, F=120.12, p<0.001$, 
TABLE 1 | Seasonal variation (mean \pm SD) of estuarine and atmospheric $\mathrm{CH}_{4}$ concentrations, oxidation and exchanges across different interfaces.

\begin{tabular}{|c|c|c|c|c|}
\hline Parameters & Position & Pre-monsoon & Monsoon & Post-monsoon \\
\hline \multirow[t]{2}{*}{ Estuarine $\mathrm{CH}_{4}$ conc. (nM) } & Surface & $54.20 \pm 5.06$ & $64.58 \pm 10.56$ & $90.91 \pm 21.20$ \\
\hline & Sub-surface & $47.28 \pm 12.85$ & $53.27 \pm 19.47$ & $67.97 \pm 33.12$ \\
\hline Dissolved $\mathrm{CH}_{4}$ ox. $\left(\mathrm{nmol} \mathrm{L}^{-1} \mathrm{~d}^{-1}\right)$ & Surface & $30.24 \pm 6.48$ & $18.58 \pm 3.00$ & $12.96 \pm 2.88$ \\
\hline Water-atmosphere $\mathrm{CH}_{4}$ flux $\left(\mu \mathrm{mol} \mathrm{m}{ }^{-2} \mathrm{~d}^{-1}\right)$ & & $6.27 \pm 1.61$ & $10.67 \pm 6.92$ & $9.70 \pm 1.88$ \\
\hline \multirow[t]{2}{*}{ Atm. $\mathrm{CH}_{4}$ conc. (ppmv) } & $10 \mathrm{~m}$ & $1.769 \pm 0.04$ & $2.180 \pm 0.12$ & $2.112 \pm 0.05$ \\
\hline & $20 \mathrm{~m}$ & $1.821 \pm 0.09$ & $2.027 \pm 0.03$ & $2.116 \pm 0.06$ \\
\hline Biosphere-atmosphere $\mathrm{CH}_{4}$ flux $\left(\mu \mathrm{mol} \mathrm{m} \mathrm{m}^{-2} \mathrm{~d}^{-1}\right)$ & & $-6,771$ & 9,953 & $-3,165$ \\
\hline$\left[\mathrm{CH}_{4}\right]$ photo-ox rate $\left(\right.$ molecules $\left.\mathrm{cm}^{-3} \mathrm{~d}^{-1}\right)$ & 10 & $1.40 \times 10^{11}$ & $1.67 \times 10^{11}$ & $6.05 \times 10^{10}$ \\
\hline
\end{tabular}

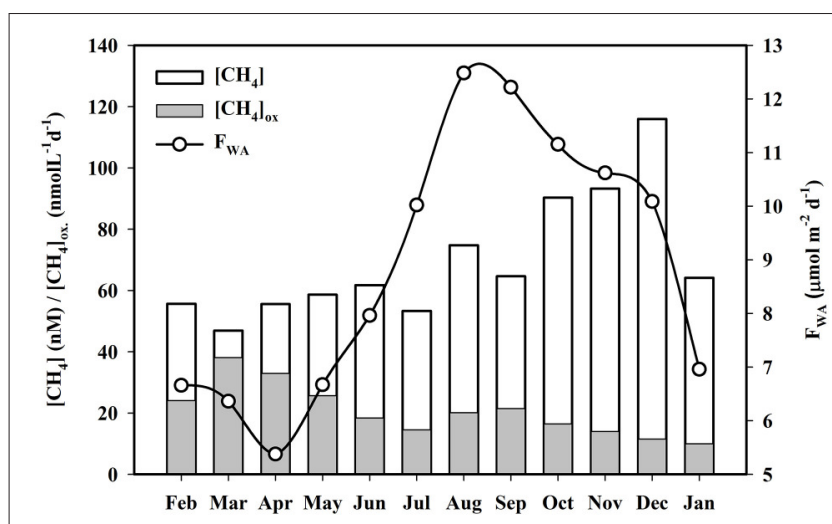

FIGURE 10 | Monthly variations of estuarine dissolved $\mathrm{CH}_{4}$ conc., $\mathrm{CH}_{4}$ oxidation, and air-water $\mathrm{CH}_{4}$ exchange flux ( $F_{\text {WA }}$ )

$n=8$; post-monsoon: $R^{2}=75.8 \%, F=18.83, p=$ $0.005, n=8)$, indicating that salinity is the major governing factor for variability of $\mathrm{CH}_{4}$ concentration in this estuary. This same pattern has been shown for other tropical and subtropical estuaries (Upstill-Goddard et al., 2000; Middelburg et al., 2002; Biswas et al., 2007; Zhang et al., 2008). Moreover, Dutta et al. (2015a) established that much of the dissolved $\mathrm{CH}_{4}$ in the estuarine system of Sundarbans was from exogenous sources.

\section{Dissolved $\mathrm{CH}_{4}$ Oxidation in Saptamukhi River Estuary} The Saptamukhi River estuarine water column is a welloxygenated system that favors the activity of methanotrophs. Other studies have shown the mean dissolved $\mathrm{CH}_{4}$ oxidation rate in these estuarine surface waters to be $20.59 \mathrm{nmol} \mathrm{L}^{-1} \mathrm{~d}^{-1}$, and varies between $12.96 \pm 2.88$ and $30.24 \pm 6.48 \mathrm{nmol} \mathrm{L}^{-1} \mathrm{~d}^{-1}$ (Table 1) (Dutta et al., 2015a). Seasonally, $\mathrm{CH}_{4}$ oxidation rates during the pre-monsoon period were significantly $[p(=0.002)$ $<0.05]$ higher than post-monsoon periods (Figure 10). Aquatic $\mathrm{CH}_{4}$ oxidation has been shown to be significantly impacted by other physicochemical parameters such as temperature (thermal), salinity (tonicity), oxygen (oxidative), DIN (nutrient), and turbidity (surface). In the case of turbidity, estuarine methanotrophs, associated with suspended particulate matter, may be more effeicient in oxidizing $\mathrm{CH}_{4}$ in the water column (Abril et al., 2007). Considering dissolved $\mathrm{CH}_{4}$ oxidation rate $\left(\left[\mathrm{CH}_{4}\right]_{\text {DOX }}\right)$ as dependent variable, relative to other independent parameters measured (T, S, DO, [DIN] and $\mathrm{S}_{\mathrm{D}}$ ), a multiple regression analysis $\left(\left[\mathrm{CH}_{4}\right]_{\mathrm{DOX}}=-61.8+0.732 \mathrm{~T}+1.97 \mathrm{~s}+7.24\right.$ DO $-0.456 \mathrm{DIN}-0.290 \mathrm{~S}_{\mathrm{D}} ; R^{2}=90.8 \%, F=11.91, p=0.005$, $n=12)$ revealed a significant correlation between $\left[\mathrm{CH}_{4}\right]_{\text {DOX }}$ with only $\mathrm{S}(p=0.002)$, $\mathrm{DO}(p=0.037)$ and $\mathrm{S}_{\mathrm{D}}(p=0.019)$, but not with others. This further supports the need to examine broader spectrum and variability of drivers on $\mathrm{CH}_{4}$ oxidation in these complex estuarine waters.

\section{Saturation Percentage of $\mathrm{CH}_{4}$ and Air-Water $\mathrm{CH}_{4}$ Exchange}

Percent saturation of dissolved $\mathrm{CH}_{4}$ in the Saptamukhi River estuary ranged from $2,483 \pm 950$ to $3,525 \pm 1,054$, indicating that estuarine waters were supersaturated in $\mathrm{CH}_{4}$, highly conducive for $\mathrm{CH}_{4}$ efflux across the water-atmosphere interface. Seasonal variability in $\mathrm{CH}_{4}$ exchange across air-water interface of this estuary are shown in Figure 10 (Dutta et al., 2015a). Flux values calculated during the monsoon period $\left(10.67 \pm 6.92 \mu \mathrm{mol} \mathrm{m}^{-2}\right.$ $\left.\mathrm{d}^{-1}\right)$ were significantly higher $[p(=0.007)<0.05]$ compared to pre-monsoon conditions $\left(6.27 \pm 1.61 \mu \mathrm{mol} \mathrm{m} \mathrm{m}^{-2} \mathrm{~d}^{-1}\right)$ (Table 1). Air-water $\mathrm{CH}_{4}$ fluxes were in the range of that calculated for other tropical estuaries, like the Hooghly estuary (0.88$\left.148.63 \mu \mathrm{mol} \mathrm{m}{ }^{-2} \mathrm{~d}^{-1}\right)$ and Yangtze River estuary $(6-25 \mu \mathrm{mol}$ $\mathrm{m}^{-2} \mathrm{~d}^{-1}$ ) (Biswas et al., 2007; Zhang et al., 2008). The lowest $\mathrm{CH}_{4}$ fluxes during pre-monsoon season were likely attributed to the coupled impact of low wind speeds, resulting low gas transfer velocities, as well as low dissolved $\mathrm{CH}_{4}$ concentrations in surface waters. Estimated $\mathrm{CH}_{4}$ flux values estimated for the Saptamukhi River estuary showed asignificant correlations with water temperature and salinity (water temperature: $R^{2}=61 \%$, $F=6.71, p=0.029, n=24$; salinity: $R^{2}=54 \%, F=5.31$, $p=0.037, n=24)$, indicating cumulative effects of temperature and salinity on $\mathrm{CH}_{4}$ emission fluxes (Dutta et al., 2015a). On an annual basis, the mean $\mathrm{CH}_{4}$ emission flux across the wateratmosphere interface was $8.88 \mu \mathrm{mol} \mathrm{m} \mathrm{m}^{-2} \mathrm{~d}^{-1}$, indicating that the estuary acted as a source of $\mathrm{CH}_{4}$ to the regional atmosphere during this study period. 


\section{Atmospheric $\mathrm{CH}_{4}$ Dynamics at Lothian Island in the Indian Sundarbans Micrometeorology and Atmospheric $\mathrm{CH}_{4}$ Mixing Ratio}

Previous work has shown that the lowest air temperatures and wind velocities, on Lothian Island, occurred during the post-monsoon season and were at their maximum during premonsoon conditions (Dutta et al., 2015b). Friction velocity (u*), which controls stability of the atmosphere (e.g., atmospheric turbulence), varied between 0.01 and $1.2 \mathrm{~m} \mathrm{~s}^{-1}$. PBL heights over the mangrove forest atmosphere (702.45 to $936.59 \mathrm{~m}$ ), and were highest and lowest during pre-monsoon and monsoon periods, respectively. The values of drag coefficient $(0.16-0.39)$ and roughness height (varied between $1.63 \pm 1.02$ and $3.77 \pm$ $3.01 \mathrm{~m}$ ) also followed the same seasonal trends.

Dutta et al. (2015b) measured atmospheric $\mathrm{CH}_{4}$ mixing ratios at 10 and $20 \mathrm{~m}$ heights in the mangrove forest on Lothian Island (Figure 11). The lowest atmospheric $\mathrm{CH}_{4}$ mixing ratios were observed during pre-monsoon (at both 10 and $20 \mathrm{~m}$ heights) season, while maximum ratios were found during monsoon and post-monsoon periods for $10 \mathrm{~m}$ and $20 \mathrm{~m}$ heights, respectively (Table 1). The significantly higher $\mathrm{CH}_{4}$ concentrations in air $[p(=0.001)<0.05]$ at $10 \mathrm{~m}$ height during monsoon season, compared to pre-monsoon, may be attributed to peak monsoon $\mathrm{CH}_{4}$ emissions from sediments and aquatic surfaces, which primarily contribute to lower atmospheric $\mathrm{CH}_{4}$ pool. We have also shown peak $\mathrm{CH}_{4}$ concentrations in air occurring during early morning, which may be attributed to $\mathrm{CH}_{4}$ accumulation within a stable boundary layer during that period (Dutta et al., 2015b). Concentrations of $\mathrm{CH}_{4}$ in the lower atmosphere have been shown to decrease with advancing daylight due to increases in atmospheric turbulence-which tends to breakup a stable boundary layer (Mukhopadhyay et al., 2002). The atmospheric stability parameter $(\mathrm{Z} / \mathrm{L})$ and $\mathrm{CH}_{4}$ mixing ratio (at $10 \mathrm{~m}$ height) were significantly correlated $\left(R^{2}=\right.$ $74.8 \%, p<0.001, F=29.73, n=30$ ), this further supports that micrometeorology plays an important role in the variability of $\mathrm{CH}_{4}$ mixing ratio in the lower atmosphere of mangrove forests in the Indian Sundarbans (Dutta et al., 2015b).

\section{Exchanges of $\mathrm{CH}_{4}$ across Biosphere-Atmosphere Interface}

On an annual basis, atmosphere $\mathrm{CH}_{4}$ mixing ratios measured at $10 \mathrm{~m}$ height over Lothian Island were $2 \%$ higher compared to 20 $\mathrm{m}$, indicating $\mathrm{CH}_{4}$ exchanges across the biosphere-atmosphere interface that were modulated by atmospheric turbulence. Our previous work (Dutta et al., 2015b) has shown monthly $\mathrm{CH}_{4}$ exchange fluxes of across mangrove biosphere-atmosphere interface (Figure 11), that have maximal fluxes during monsoon and minimal during post-monsoon periods (Table 1). These values also confirmed that mangroves were a $\mathrm{CH}_{4}$ source to the upper atmosphere during the monsoon period (flux values positive), when $\Delta \chi$ was a significantly positive sink, in contrast to periods during pre-and post-monsoon seasons (flux values negative), when $\Delta \chi$ was negative. During the observation period,

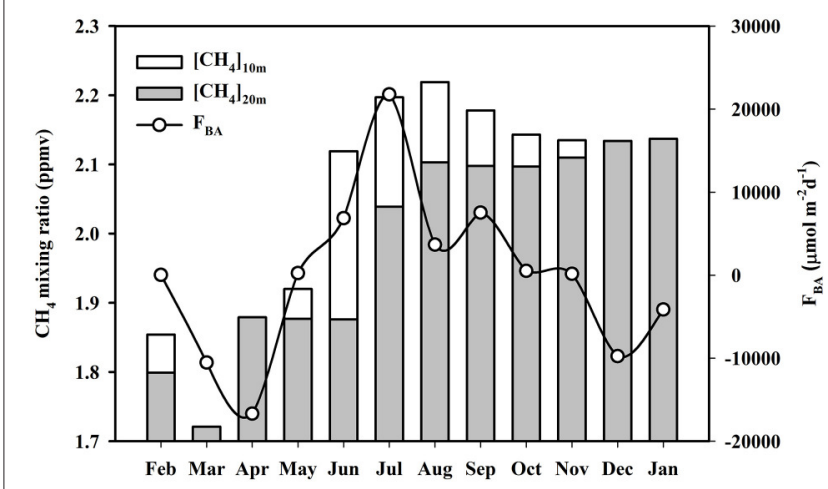

FIGURE 11 | Monthly variations of atmospheric $\mathrm{CH}_{4}$ mixing ratio at 10 and $20 \mathrm{~m}$ heights and biosphere-atmosphere $\mathrm{CH}_{4}$ exchange flux $\left(\mathrm{F}_{\mathrm{BA}}\right)$.

the mean mangrove biosphere-atmosphere $\mathrm{CH}_{4}$ exchange flux was estimated to be $5.5 \mu \mathrm{mol} \mathrm{m}{ }^{-2} \mathrm{~d}^{-1}$, which indicated that on an annual basis these mangroves were dominant sources of $\mathrm{CH}_{4}$ to the upper atmosphere. The mean compensation point, where the net biosphere-atmosphere $\mathrm{CH}_{4}$ flux is zero, was found to be 1.997 ppmv. Sensible heat flux (H), which moderately controls atmospheric transport of energy and mass, was significantly correlated with biosphere-atmosphere $\mathrm{CH}_{4}$ flux $\left(\mathrm{F}_{\mathrm{BA}}\right)$. This was defined by a second order polynomial relationship $\left(R^{2}=0.53\right.$, $F=7.72, p=0.002, n=12$ ), further supporting the significant influence of sensible heat flux on the variability of biosphere-atmosphere $\mathrm{CH}_{4}$ exchange fluxes (Dutta et al., 2015b).

\section{Atmospheric $\mathrm{CH}_{4}$ Photo-Oxidation}

On annual basis, the mean daytime $\mathrm{CH}_{4}$ mixing ratio was estimated to be 1.03 times lower than at nighttime; this variability is expected to be cumulatively governed by photo-oxidation and diurnal changes of PBL height. Dutta et al. (2015b) reported an insignificant correlation between daytime and nighttime $\mathrm{CH}_{4}$ mixing ratios with PBL height $\left(\Delta \mathrm{CH}_{4}=-0.0118 \Delta \mathrm{PBL}+0.3045\right.$; $R^{2}=16.2 \%, F=0.321, p=0.987, n=12$ ), and for the first time, showed the presence of $\mathrm{CH}_{4}$ photo-oxidation within this tropical mangrove forest atmosphere. More specifically, this work reported $\mathrm{CH}_{4}$ photo-oxidation rates in the forest atmosphere that varied between $6.05 \times 10^{10}$ and $1.67 \times 10^{11}$ molecules $\mathrm{cm}^{-3}$ $\mathrm{d}^{-1}$, and were maximal and minimal during monsoon and postmonsoon periods, respectively (Table 1). The significantly higher monsoon $\mathrm{CH}_{4}$ photo-oxidation rate $\left[p\left(=3.2 \times 10^{-7}\right)<0.05\right]$ compared to post-monsoon, may be attributed to the combined effect of maximum $\mathrm{CH}_{4}$ influx to atmosphere through emissions across sediment-atmosphere and water-atmosphere interfaces-as well as high UV indices and UV erythermal doses of irradiance that occur during this period in subtropical latitudes (Panicker et al., 2014). When considering a mean day light period of $12 \mathrm{~h}$ and that $6.023 \times 10^{23}$ molecules equals to 1 mole or $16,000 \mathrm{mg}$ $\mathrm{CH}_{4}$, the mean $\mathrm{CH}_{4}$ photo-oxidation rate to the atmosphere in this tropical mangrove-dominated island was calculated to be $3.25 \times 10^{-9} \mathrm{mg} \mathrm{cm}^{-3} \mathrm{~d}^{-1}$. 


\section{Quantitative $\mathrm{CH}_{4}$ Budget for Sundarbans Mangrove Ecosystem}

A box model was developed on the biogeochemical cycling of $\mathrm{CH}_{4}$-as well as a quantitative $\mathrm{CH}_{4}$ budget for the Sundarbans mangrove ecosystem (Figure 12). In the model different subecosystems are designated as separate reservoirs. The $\mathrm{CH}_{4}$ pool in each reservoir and exchange fluxes between different reservoirs are presented on an annual mean basis. The major outputs from the box model are described below.

\section{Mangrove/Intertidal Sediment Methane Budget}

Total annual $\mathrm{CH}_{4}$ production in Sundarbans mangrove sediment, within an intertidal sediment depth of $25 \mathrm{~cm}$, was estimated to be $21.7 \mathrm{Gg}_{\text {year }}{ }^{-1}$, with a daily rate of $3,547 \mu \mathrm{mol}$ $\mathrm{m}^{-3} \mathrm{~d}^{-1}$. The $\mathrm{CH}_{4}$ sediment reservoir pool was $0.03 \mathrm{Gg}$, with a mean pore-water $\mathrm{CH}_{4}$ concentration $3,451 \mathrm{nM}$. Pore water was $\sim 55$ times more supersaturated than adjacent estuarine waters $(63.0 \mathrm{nM})$. This suggests that during low tide, depending upon the hypsometric gradient, there is a significant outflux of $\mathrm{CH}_{4}$-rich pore water from the intertidal mangrove sediments to estuary, via advective transport. Extrapolating a mean advective $\mathrm{CH}_{4}$ influx from mangrove sediment to the adjacent estuary $\left(159.5 \mu \mathrm{mol} \mathrm{m} \mathrm{m}^{-2} \mathrm{~d}^{-1}\right)$ for entire intertidal area of Indian Sundarbans (45\% of total forest area; http:// www.sundarbanbiosphere.org/html_files/sunderban_biosphere_ reserve.htm), we estimate that about $8.2 \%$ of the total mangrove sediment produced $\mathrm{CH}_{4}$ is advectively transported to the adjacent estuarine system, with $\sim 12.4 \%$ undergoing oxidation at sediment surface by methanotrophs. Total annual $\mathrm{CH}_{4}$ emission, from intertidal mangrove sediment to the forest atmosphere, was estimated to be $10.8 \mathrm{Gg}$ year $^{-1}(\sim 49.6 \%$ of total produced $\mathrm{CH}_{4}$ in sediment), with a mean daily rate of $7.1 \mathrm{mg} \mathrm{m}^{-2} \mathrm{~d}^{-1}$. When examining the ratio of [sediment emission]: [aerobic oxidation]: [advective flux], which computes to 6.05:1.51:1, it reveals that $\mathrm{CH}_{4}$ emission is major $\mathrm{CH}_{4}$ removal mechanism in these intertidal mangrove sediments. Excess $\mathrm{CH}_{4}$ remaining $\left(\left[\Delta \mathrm{CH}_{4}\right]_{\mathrm{S}}\right)$ in these mangrove sediments, beyond the aforementioned "sink" mechanisms, was computed as follows:

$\left[\Delta \mathrm{CH}_{4}\right]_{S}=$ Total $\mathrm{CH}_{4}$ production - Total outflux (sediment emission + aerobic oxidation + advective flux). When using this equation, we find sink value $\left[\Delta \mathrm{CH}_{4}\right]_{S}$ of $6.4 \mathrm{Gg}$ year ${ }^{-1}$. This estimated value reflects the removal of $\mathrm{CH}_{4}$, via anaerobic methane oxidation (AMO), within sub-surface mangrove sediments, that were not considered in this study.

\section{Sub-Tidal Sediment $\mathrm{CH}_{4}$ Budget}

Total $\mathrm{CH}_{4}$ production at the $0-5 \mathrm{~cm}$ depth of sub-tidal sediment was $0.03 \mathrm{Gg}$ year ${ }^{-1}$, with a mean of $48.88 \mu \mathrm{mol} \mathrm{m}^{-3} \mathrm{~d}^{-1}$. Mean sub-tidal sediment pore-water $\mathrm{CH}_{4}$ concentration was $3,286 \mathrm{nM}$; which was $\sim 52.1$ times supersaturated, compared to overlying estuarine water $\mathrm{CH}_{4}$ levels. This supports the notion of diffusive $\mathrm{CH}_{4}$ transport mechanism from sub-tidal sediments to the overlying estuary. On annual basis total diffusive $\mathrm{CH}_{4}$ influx from sub-tidal sediment to the overlying estuary was $0.09 \mathrm{Gg}$, with a mean of $8.4 \mu \mathrm{mol} \mathrm{m}^{-2} \mathrm{~d}^{-1}$.

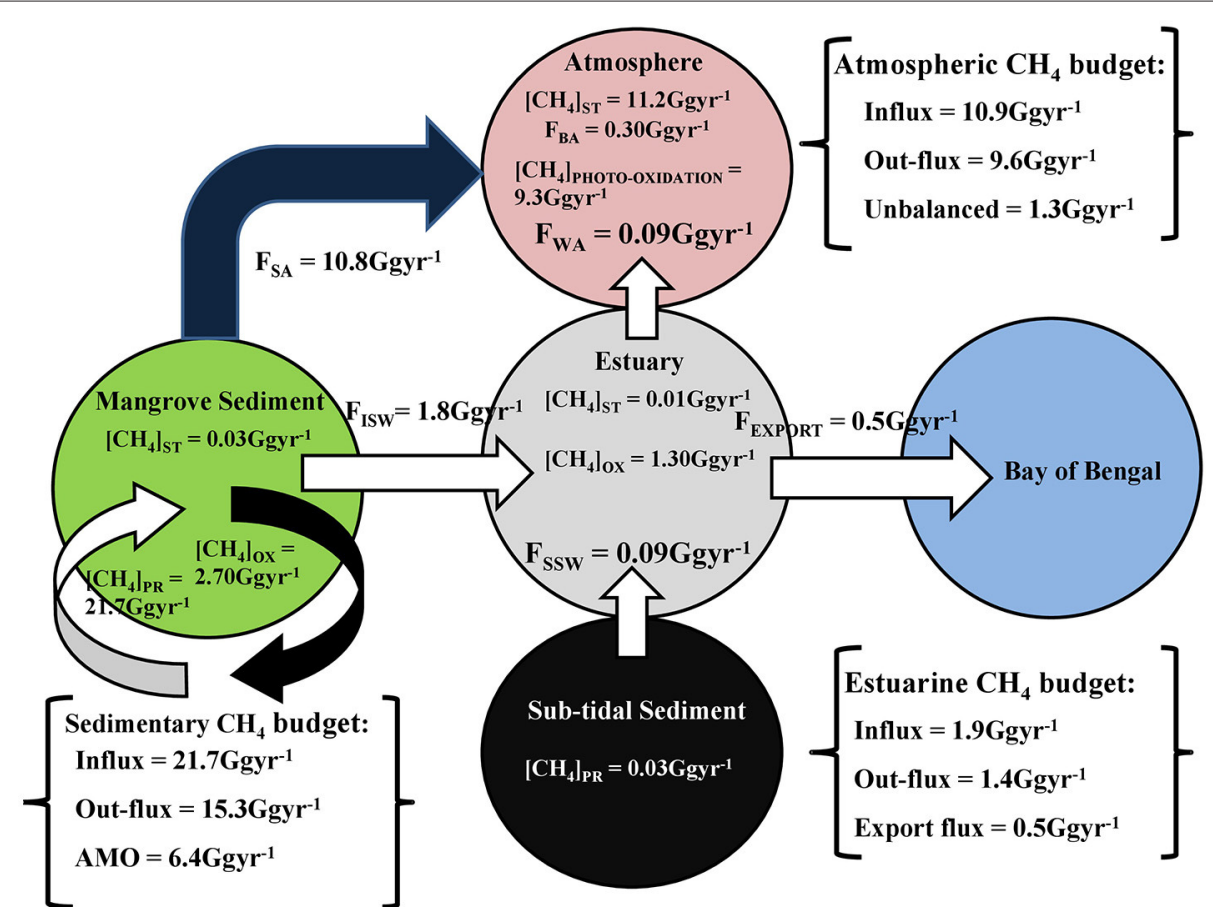

FIGURE 12 | Biogeochemical $\mathrm{CH}_{4}$ cycling at Indian Sundarbans. Here, $\left[\mathrm{CH}_{4}\right]_{\mathrm{ST}}=\mathrm{CH}_{4}$ storage, $\left[\mathrm{CH}_{4}\right]_{\mathrm{PR}}=\mathrm{CH}_{4}$ production, $\left[\mathrm{CH}_{4}\right]_{\mathrm{OX}}=\mathrm{CH}_{4}$ oxidation, $\mathrm{F}_{\mid \mathrm{SW}}=$ advective $\mathrm{CH}_{4}$ flux, $\mathrm{F}_{\mathrm{SSW}}=$ diffusive $\mathrm{CH}_{4}$ flux, $\mathrm{F}_{\mathrm{SA}}=$ mangrove sediment-atmosphere $\mathrm{CH}_{4}$ flux, $\mathrm{F}_{\mathrm{BA}}=$ mangrove biosphere-atmosphere $\mathrm{CH}_{4}$ flux, and $\mathrm{F}_{\mathrm{EXPORT}}=$ $\mathrm{CH}_{4}$ export flux from estuary to northern Bay of Bengal. 


\section{Estuarine $\mathrm{CH}_{4}$ Budget}

The total $\mathrm{CH}_{4}$ input to the Saptamukhi River estuary (by both advectice and diffusive transport) was $1.8 \mathrm{Gg}_{\text {year }}{ }^{-1}$. The ratio between advective and diffusive $\mathrm{CH}_{4}$ flux was 20:1, indicating that advective $\mathrm{CH}_{4}$ flux from intertidal mangrove sediments was the dominant driver in the buildup of the estuarine $\mathrm{CH}_{4}$ pool. The estuary stands as a reservoir pool of $0.01 \mathrm{Gg} \mathrm{CH}_{4}$, having a mean concentration of $63.0 \mathrm{nM}$. An estimated $74.5 \%$ of total $\mathrm{CH}_{4}$ supplied to the estuary was removed from the estuarine systemvia microbial oxidation, with only $5.0 \%$ lost by an air-water $\mathrm{CH}_{4}$ exchange flux. The ratio between microbial oxidation and airwater $\mathrm{CH}_{4}$ exchange flux was 14:1, indicating microbial oxidation was the principal $\mathrm{CH}_{4}$ removal pathway in this estuary. Mean turnover time of $\mathrm{CH}_{4}$ in the water column relative to oxidation and emission was 3.7 days. After oxidation and emission, excess $\mathrm{CH}_{4}$ left $\left(\left[\Delta \mathrm{CH}_{4}\right]_{\mathrm{E}}\right)$ in the estuarine system was computed as:

$$
\begin{aligned}
{\left[\mathrm{CCH}_{4}\right]_{\mathrm{E}}=} & \text { Total influx (Advective }+ \text { Diffusive }) \\
& - \text { Total outflux (microbial oxidation } \\
& + \text { estuarine emission) }
\end{aligned}
$$

Using the equation, $\left[\Delta \mathrm{CH}_{4}\right]_{\mathrm{E}}$ was computed as $0.5 \mathrm{Gg}$ year ${ }^{-1}$, which is estimated $\mathrm{CH}_{4}$ exported to the adjacent continental shelf region, thereby enriching the $\mathrm{CH}_{4}$ pool in northern Bay of Bengal.

\section{Atmospheric $\mathrm{CH}_{4}$ Budget}

The total annual $\mathrm{CH}_{4}$ influx for Sundarbans mangrove ecosystem, via mangrove sediment and estuarine emissions, was $10.9 \mathrm{Gg}$ year $^{-1}$, of which $99.1 \%$ was from sediments. Atmospheric $\mathrm{CH}_{4}$ mixing ratios at 10 and $20 \mathrm{~m}$ heights in the forest atmosphere were 2.03 and 1.98 ppmv, respectively having mean of 2 ppmv. Extrapolating over entire Sundarbans, up to the mean PBL height $(811.7 \mathrm{~m})$, the atmosphere stands as a reservoir pool of $11.2 \mathrm{Gg} \mathrm{CH}_{4}$. The annual mean mangrove biosphere-atmosphere $\mathrm{CH}_{4}$ exchange flux was estimated to be $5.38 \mu \mathrm{mol} \mathrm{m} \mathrm{m}^{-2} \mathrm{~d}^{-1}$. However, when extrapolated for entire forest area it was found that only $2.75 \%$ of total annual $\mathrm{CH}_{4}$ influx to the forest atmosphere was transported to the upper forest atmosphere. Moreover, $\sim 85 \%$ of total annual $\mathrm{CH}_{4}$ influx to the forest atmosphere experienced photo-oxidation within the atmospheric boundary layer of Sundarbans, with a mean rate of $3.25 \times 10^{-9} \mathrm{mg} \mathrm{cm}^{-3} \mathrm{~d}^{-1}$. Excess $\mathrm{CH}_{4}$ that was from the forest atmosphere $\left(\left[\Delta \mathrm{CH}_{4}\right]_{\mathrm{A}}\right)$ beyond the photooxidation and biosphere-atmosphere fluxes was calculated as follows:

$$
\begin{aligned}
{\left[\Delta \mathrm{CH}_{4}\right]_{\mathrm{A}}=} & \text { Total influx (estuarine emission } \\
& + \text { sediment emission) } \\
& - \text { Total outflux(photo-oxidation } \\
& + \text { biosphere-atmosphere flux) }
\end{aligned}
$$

Using this mass balance equation $\left[\Delta \mathrm{CH}_{4}\right]_{\mathrm{A}}$, we estimated that $1.3 \mathrm{Gg}$ year ${ }^{-1}$ enriches the regional atmospheric $\mathrm{CH}_{4}$ mixing ratio and further contributes to regional climate change scenarios. The impact of these gases need to be considered as a delineated reservoir, within the context of a regional climate and atmospheric boundary layer height (ABL) (mean height $=$ $811.7 \mathrm{~m}$; Dutta et al., 2015b). Considering a radiative forcing efficiency of $\mathrm{CH}_{4}$ in the atmosphere as $3.7 \times 10^{-4} \mathrm{~W} \mathrm{~m}^{-2}$ $\mathrm{ppb}^{-1}$ (https://www.ipcc.ch/publications_and_data/ar4/wg1/en/ ch2s2-10-2.html), $\left[\Delta \mathrm{CH}_{4}\right]_{\mathrm{A}}$ in this mangrove forest atmosphere resulted $0.11 \mathrm{Wm}^{-2}$ year $^{-1}$ of radiative forcing to the regional atmosphere.

\section{CONCLUSIONS}

In intertidal mangrove sediment column $\mathrm{CH}_{4}$ production rate, down to depth of $25 \mathrm{~cm}$ in the sediments, was estimated to be $21.75 \mathrm{Gg}_{\text {year }}{ }^{-1}$ with a mean pore water $\mathrm{CH}_{4}$ concentration was 3,541 nM. $\mathrm{CH}_{4}$ emission across intertidal sediment-atmosphere interface acted as major sink for the $\mathrm{CH}_{4}$ produced in intertidal sediments over surface layer $\mathrm{CH}_{4}$ oxidation and advective $\mathrm{CH}_{4}$ transport to Saptamukhi River estuary. The estuary, which was well-oxygenated, which constrained methanogenesis within estuarine water column, where dissolved $\mathrm{CH}_{4}$ was considered to be entirely exogenous in nature. Advective $\mathrm{CH}_{4}$ flux, which was 20 times higher than diffusive flux, was the major source for $\mathrm{CH}_{4}$ to the estuary. $\mathrm{CH}_{4}$ oxidation which is 14 times higher than the water-atmosphere exchange, was considered the principal $\mathrm{CH}_{4}$ removal mechanism in this estuary. On an annual basis, total $\mathrm{CH}_{4}$ emissions from sediments and waters of the Sundarbans mangrove biosphere was $10.9 \mathrm{Gg}$ of which sediment contributed principally $99.1 \%$. Compared to total $\mathrm{CH}_{4}$ supply to the forest atmosphere, about $85 \%$ photooxidized within atmospheric boundary layer of Sundarbans while $2.75 \%$ is transported to the upper atmosphere through mangrove biosphere-atmosphere $\mathrm{CH}_{4}$ exchange flux. Based on our proposed $\mathrm{CH}_{4}$ budget the mangrove forest atmosphere resulted in a radiative forcing $0.11 \mathrm{Wm}^{-2}$ year $^{-1}$ to the regional atmosphere.

\section{AUTHOR CONTRIBUTIONS}

MD and SM: Have desinged the investigations, data genaration as well as manuscript preparation. The author TB has corrected the manuscript and made significant improvement of the manuscript.

\section{ACKNOWLEDGMENTS}

The authors thank the Ministry of Earth Science, Govt. of India sponsored Sustained Indian Ocean Biogeochemistry and Ecological Research (SIBER) proggrame for providing financial support to carry out the study. We are thankful to the Sundarbans Biosphere Reserve for extending necessary help and support for conducting fieldwork and measurements related to the study. 


\section{REFERENCES}

Abril, G., Commarieu, M. V., and Guérin, F. (2007). Enhanced methane oxidation in an estuarine turbidity maximum. Limnol. Oceanogr. 52, 470-475. doi: $10.4319 /$ lo.2007.52.1.0470

Alongi, D. M. (2012). Carbon sequestration in mangrove forests. Carbon Manage. 3, 313-322. doi: $10.4155 / \mathrm{cmt} .12 .20$

Alongi, D. M. (2014). Carbon cycling and storage in Mangrove forests. Ann. Rev. Mar. Sci. 6, 195-219. doi: 10.1146/annurev-marine-010213-135020

Barrett, K. (1998). Oceanic ammonia emissions in Europe and their transboundary fluxes. Atmos. Environ. 32, 381-391. doi: 10.1016/S1352-2310(97)00279-3

Bartlett, K. B., Bartlett, D. S., Harris, R. C., and Sebacher, D. I. (1987). Methane emissions along a salt marsh gradient. Biogeochemistry 4, 183-202. doi: $10.1007 / \mathrm{BF} 02187365$

Bastviken, D., Tranvik, L. J., Downing, J. A., Crill, P. M., and Enrich-Prast, A. (2011). Freshwater methane emissions offset the continental carbon sink. Science 331:50. doi: 10.1126/science.1196808

Bauer, S. E., Bausch, A., Nazarenko, L., Tsigaridis, K., Xu, B., Edwards, R., et al. (2013). Historical and future black carbon deposition on the three ice caps: Icecore measurements and model simulations from 1850 to 2100. J. Geophys. Res. Atmos. 118, 7948-7961. doi: 10.1002/jgrd.50612

Bianchi, T. S., Freer, M. E., and Wetzel, R. G. (1996). Temporal and spatial variability, and the role of dissolved organic carbon (DOC) in methane fluxes from the Sabine River Floodplain (Southeast Texas, U.S.A.). Arch. Hydrobiol. I36, 261-287.

Biswas, H., Mukhopadhyay, S. K., De, T. K., Sen, S., and Jana, T. K. (2004). Biogenic controls on the air-water carbon dioxide exchange in the Sundarban mangrove environment, northeast coast of Bay of Bengal, India. Limnol. Oceanogr. 49, 95-101. doi: 10.4319/lo.2004.49.1.0095

Biswas, H., Mukhopadhyay, S. K., Sen, S., and Jana, T. K. (2007). Spatial and temporal patterns of methane dynamics in the tropical mangrove dominated estuary, NE Coast of Bay of Bengal, India. J. Mar. Syst. 68, 55-64. doi: 10.1016/j.jmarsys.2006.11.001

Bouillon, S., Borges, A. V., Moya, E. C., and Diele, K., (2008). Mangrove production and carbon sinks: a revision of global budget estimates. Glob. Biogeochem. Cycles 22:GB2013. doi: 10.1029/2007GB003052

Bouillon, S., Guebas, F. D., Rao, A. V. V. S., Koedam, N., and Dehairs, F. (2004). Sources of organic carbon in mangrove sediments: variability and possible ecological implications. Hydrobiologia 495, 33-39. doi: 10.1023/A:1025411506526

Bradford, M. A., Ineson, P., Wookey, P. A., and Lappin-Scott, H. M. (2001). The effects of acid nitrogen and acid sulphur deposition on $\mathrm{CH} 4$ oxidation in a forest soil: a laboratory study. Soil Biol. Biochem. 33, 1695-1702. doi: 10.1016/S0038-0717(01)00091-8

Bridgham, S. D., Cadillo-Quiroz, H., Keller, J. K., and Zhuang, Q. (2013). Methane emissions from wetlands: biogeochemical, microbial, and modeling perspectives from local to global scales. Glob. Chang. Biol. 19, 1325-1346. doi: $10.1111 /$ gcb.12131

Canfield, D. E., Kristensen, E., and Thamdrup, B. O. (2005). The sulfur cycle. $A d v$. Mar. Biol. 48, 313-381. doi: 10.1016/S0065-2881(05)48009-8

Chanton, J. P., and Dacey, J. W. H. (1991). "Effects of vegetation on methane flux, reservoirs and carbon isotopic composition," in Trace Gas Emissions from Plants eds H. Mooney, E. Holland, and T.Sharkey (San Diego, CA: Academic Press), 65-92.

Craft, C., Clough, J., Ehman, J., Joye, S., Park, R., Pennings, S., et al. (2009). Forecasting the effects of accelerated sea level rise on tidal marsh ecosystem services. Front. Ecol. Environ. 7, 73-78. doi: 10.1890/070219

Deborde, J., Anschutz, P., Guerin, F., Poirier, D., Marty, D., Boucher, G., et al. (2010). Methane sources, sinks and fluxes in a temperate tidal Lagoon: the Arcachon lagoon (SW France). Estuar. Coast. Shelf Sci. 89, 256-266. doi: 10.1016/j.ecss.2010.07.013

Deborde, J., Marchand, C., Molnar, N., Patrona, L. D., and Meziane, T. (2015). Concentrations and Fractionation of Carbon, Iron, Sulfur, Nitrogen and Phosphorus in Mangrove Sediments Along an Intertidal Gradient (Semi-Arid Climate, New Caledonia). J. Mar. Sci. Eng. 3, 52-72. doi: 10.3390/jmse30 10052

Donato, D. C., Kauffman, J. B., Mackenzie, R. A., Ainsworth, A., and Pfleeger, A. Z. (2012). Whole-island carbon stocks in the tropical Pacific: implications for mangrove conservation and upland restoration. J. Environ. Manage. 97, 89-96. doi: 10.1016/j.jenvman.2011.12.004

Dutta, M. K., Chowdhury, C., Jana, T. K., and Mukhopadhyay, S. K. (2013). Dynamics and exchange fluxes of methane in the estuarine mangrove environment of Sundarbans, NE coast of India. Atmos. Environ. 77, 631-639. doi: 10.1016/j.atmosenv.2013.05.050

Dutta, M. K., Mukherkjee, R., Jana, T. K., and Mukhopadhyay, S. K. (2015a). Biogeochemical dynamics of exogenous methane in an estuary associated to a mangrove biosphere; the Sundarbans, NE coast of India. Mar. Chem. 170, 1-10. doi: 10.1016/j.marchem.2014.12.006

Dutta, M. K., Mukherkjee, R., Jana, T. K., and Mukhopadhyay, S. K. (2015b). Atmospheric fluxes and photo-oxidation of methane in the mangrove environment of the Sundarbans, NE coast of India; A case study from Lothian Island. Agric. For. Meteorol. 213, 33-41. doi: 10.1016/j.agrformet.2015.06.010

Ehhalt, D. H., and Rohrer, F. (2009). Dependence of the OH concentration on solar UV. J. Geophys. Res. 105, 3565-3571. doi: 10.1029/1999JD901070

Fiedler, S., Scholich, G. U., and Kleber, M. (2003). Innovative electrode design helps to use redox rate as a predictor for methane emissions from soils. Commun. Soil Sci. Plant Anal. 34, 481-496. doi: 10.1081/CSS-120017833

Forster, P., Ramaswamy, V., Artaxo, P., Berntsen, T. R., Betts, D. W., Fahey, J., et al. (2007). "Changes in Atmospheric constituents and in radiative forcing," in Climate Change 2007: The Physical Science Basis. Contribution of Working Group I to the Fourth Assessment Report of the Intergovernmental Panel on Climate Change, eds S. Solomon, D. Qin, M. Manning, Z. Chen, M. Marquis, K. B. Averyt, M.Tignor, and H. L. Miller (Cambridge; New York, NY: Cambridge University Press), 129-234.

Frankignoulle, M., and Borges, A. V. (2011). Direct and indirect pCO2 measurements in a wide range of $\mathrm{pCO} 2$ and salinity values (the Scheldt estuary). Aquat. Geochem. 7, 267-273. doi: 10.1023/A:1015251010481

Ganguly, D., Dey, M., Mandal, S. K., De, T. K., and Jana, T. K. (2008). Energy dynamics and its implication to biosphere-atmosphere exchange of $\mathrm{CO} 2, \mathrm{H} 2 \mathrm{O}$ and $\mathrm{CH} 4$ in a tropical mangrove forest canopy. Atmos. Environ. 42, 4172-4184. doi: 10.1016/j.atmosenv.2008.01.022

Golder, D. G. (1972). Relations among stability parameters in the surface layer. Boundary-Layer Meteorol. 3, 47-58. doi: 10.1007/BF00769106

Grasshoff, K., Ehrharft, M., and Kremling, K. (1983). Methods of Seawater Analysis, 2nd Edn. Weinheim: Verlag Chemie.

Hanson, R. S., and Hanson, T. E. (1996). Methanotrophic bacteria. Micro. and Mole. Bio. Rev. 60, 439-471.

Ho, D. T., Coffineau, N., Hickman, B., Chow, N., Koffman, T., and Schlosser, P. (2016). Influence of current velocity and wind speed on air-water gas exchange in a mangrove estuary. Geophys. Res. Lett. 43:8. doi: 10.1002/2016GL068727

Hoehler, T. M., and Alperin, M. J. (2014). Biogeochemistry: methane minimalism. Nature 507, 436-437. doi: 10.1038/nature13215

Jang, I., Lee, S., Hong, J., and Kang, H. (2006). Methane oxidation rates in forest soils and their controlling variables: a review and a case study in Korea. Ecol. Res. 21, 849-854. doi: 10.1007/s11284-006-0041-9

Jennerjahn, T., and Ittekkot, C. V. (1997). Organic matter in sediments in the mangrove areas and adjacent continental margins of Brazil: I. Amino acids and hexosamines. Oceanol. Acta 20, 359-369.

Kankaala, P., Huotari, J., Peltomaa, E., Saloranta, T., and Ojala, A. (2006). Methanotrophic activity in relation to methane efflux and total heterotrophic bacterial production in a stratified, humic, boreal lake. Limnol. Oceanogr. 51, 1195-1204. doi: 10.4319/lo.2006.51.2.1195

Kelley, C. A., Martens, C. S., and Chanton, J. P. (1990). Variations in sedimentary carbon remineralization rates in the White Oak River estuary, North Carolina. Limnol. Oceanogr. 35, 372-383. doi: 10.4319/lo.1990.35.2.0372

Knab, N. J., Cragg, B. A., Hornibrook, E. R. C., Holmkvist, L., Pancost, R. D., Borowski, C., et al. (2009). Regulation of anaerobic methane oxidation in sediments of the Black Sea. Biogeosciences 6, 1505-1518. doi: 10.5194/bg-6-1505-2009

Kristensen, E., and Alongi, D. M. (2006). Control by fiddler crabs (Uca vocans) and plant roots (Avicennia marina) on carbon, iron, and sulfur biogeochemistry in mangrove sediment. Limnol. Oceanogr. 51, 1557-1571. doi: 10.4319/lo.2006.51.4.1557

Laanbroek, H. J. (2010). Methane emission from natural wetlands: interplay between emergent macrophytes and soil microbial processes. A mini-review. Ann. Bot. 105, 141-153. doi: 10.1093/aob/mcp201 
Larsen, L., Moseman, S., Santoro, A. E., Hopfensperger, K., and Burgin, A. (2010). "A complex-systems approach to predicting effects of sea level rise and nitrogen loading on nitrogen cycling in coastal wetland ecosystems," in Ecological Dissertations in the Aquatic Sciences Symposium Proceedings VIII, Chapter 5, 67-92.

Lekphet, S., Nitisoravut, S., and Adsavakulchai, S. (2005). Estimating methane emissions from mangrove area in Ranong Province, Thailand. Songklanakarin J. Sci. Technol. 27, 153-163.

Lelieveld, J., Crutzen, P. J., and Dentener, F. J. (1993). Changing concentration, lifetime and climate forcing of atmospheric methane. Tellus 50B, 128-150.

Lessner, D. J. (2009). "Methanogenesis biochemistry," in Encyclopedia of Life Sciences (ELS), (Chichester: Wiley and Sons Ltd).

Liss, P. S., and Merlivat, L. (1986). "Air sea gas exchange rates: introduction and synthesis," in The Role of Air Sea Exchange in Geochemical Cycling, ed P. Buat-Menard (Hingham, MA: D. Reidel) 113-129.

Lu, C. Y., Wong, Y. S., Tam, N. F. Y., Ye, Y., and Lin, P. (1999). Methane flux and production from sediments of a mangrove wetland on Hainan Island China. Mangroves Salt Marshes 3, 41-49. doi: 10.1023/A:1009989026801

Marton, J. M., Herbert, E. R., and Craft, C. B. (2012). Effect of salinity on denitrification and greenhouse gas production from laboratory-incubated tidal forest soils. Wetlands 32, 347-357. doi: 10.1007/s13157-012-0270-3

Mayumi, D., Dolfing, J., Sakata, S., Maeda, H., Miyagawa, Y., and Ikarashi, M. (2013). Carbon dioxide concentration dictates alternative methanogenic pathways in oil reservoirs. Nat. Commun. 4:1998. doi: 10.1038/ncomms2998

Middelburg, J. J., Nieuwenhuize, J., Iversen, N., Hoegh, N., DeWilde, H., Helder, W., et al. (2002). Methane distribution in European tidal estuaries. Biogeochemistry 59, 95-119. doi: 10.1023/A:1015515130419

Mukhopadhyay, S. K., Biswas, H., De, T. K., Sen, S., Sen, B. K., and Jana, T. K. (2002). Impact of Sundarbans mangrove biosphere on the carbon dioxide and methane mixing ratio at the NE coast of Bay of Bengal, India. Atmos. Environ. 36, 629-638. doi: 10.1016/S1352-2310(01)00521-0

Muller, D., Bange, H. W., Warneke, T., Rixen, T., Muller, T., Mujahid, M., et al. (2016). Nitrous oxide and methane in two tropical estuaries in a peatdominated region of northwestern Borneo. Biogeosciences 13, 2415-2428. doi: 10.5194/bg-13-2415-2016

Mussa, S. A., Elferjani, H. S., Haroun, F. A., and Abdelnabi, F. F. (2009). Determination of available nitrate, phosphate and sulfate in soil samples. Int. J. PharmTech. Res. 1, 598-604.

Pal Arya, S. (2001). Introduction to Micrometeorology, 2nd Edn. New York, NY: Academic Press.

Panicker, A. S., Pandithurai, G., Beig, G., Kim, D., and Lee, D. (2014). Aerosol modulation of ultraviolet radiation dose over four metro cities in India. Adv. Meteorol. 2014:202868. doi: 10.1155/2014/202868

Panofsky, H. A., and Dutton, J. A. (1984). Atmospheric Turbulence: Models and Methods for Engineering Applications. New York, NY: John Wiley.

Prasad, B. M., Kumar, A., Ramanathan, A. L., and Datta, D. K. (2017). Sources and dynamics of sedimentary organic matter in Sundarban mangrove estuary from Indo-Gangetic delta. Ecol. Proces. 6:8. doi: 10.1186/s13717-017-0076-6

Pruppacher, H. R., and Klett, J. D. (1978). Microphysics of Clouds and Precipitation. Dordrecht: D. Reidel.

Purvaja, R., Ramesh, R., and Frenzel, P. (2004). Plant-mediated methane emission from an Indian mangrove. Glob. Chang. Biol. 10, 1-10. doi: $10.1111 / j .1365-2486.2004 .00834 . x$

Rao, G. D., and Sarma, V. V. S. S. (2016). Variability in concentrations and fluxes of methane in the Indian estuaries. Estuar. Coast. 39:1639. doi: 10.1007/s12237-016-0112-2

Ray, R., Chowdhury, C., Majumder, N., Dutta, M. K., Mukhopadhyay, S. K., and Jana, T. K. (2013). Improved model calculation of atmospheric CO2 increment in affecting carbon stock of tropical mangrove forest. Tellus B 65:18981. doi: 10.3402/tellusb.v65i0.18981

Ray, R., Ganguly, D., Chowdhury, C., Dey, M., Das, S., Dutta, M. K., et al. (2011). Carbon sequestration and annual increase of carbon stock in a mangrove forest. Atmos. Environ. 45, 5016-5024. doi: 10.1016/j.atmosenv.2011.04.074

Reay, W. G., Gallagher, D., and Simmons, G. M. (1995). Sediment Water Column Nutrient Exchanges in Southern Chesapeake Bay Near Shore Environments. Virginia Water Resources Research Centre, Bulletin- 181b.

Reeburgh, W. S. (2007). Oceanic methane biogeochemistry. Chem. Rev. 107, 486-513. doi: $10.1021 / \mathrm{cr} 050362 \mathrm{v}$
Rudolf, K. T., and Seigo, S. (2006). Methane and microbes. Nature 440, 878-879. doi: $10.1038 / 440878$ a

Saari, A., Martikainen, P. J., Ferm, A., Ruuskanen, J., De Boer, W., Troelstra, S. R., et al. (1997). Methane oxidation in soil profiles of Dutch and Finnish coniferous forests with different soil texture and atmospheric nitrogen deposition. Soil Biol. Biochem. 29, 1625-1632. doi: 10.1016/s0038-0717(97) 00085-0

Sansone, F. J., and Graham, A. W. (2004). Methane along western Mexican mergin. Limnol. Oceanogr. 49, 2242-2255. doi: 10.4319/lo.2004.49. 6.2242

Santos, I. R., Eyre, B. D., and Huettel, M. (2012). The driving forces of porewater and groundwater flow in permeable coastal sediments: a review. Estuar. Coast. Shelf Sci. 98, 1-15. doi: 10.1016/j.ecss.2011.10.024

Simpson, S. L. (2011). A Rapid screening method for acid-volatile sulfide in sediments. Environ. Toxicol. Chem. 20, 2657-2661. doi: $10.1002 /$ etc. 5620201201

Sotomayor, D., Corredor, J. E., and Morell, M. J. (1994). Methane flux from mangrove sediments along the southwestern coast of Puerto Rico. Estuaries 17, 140-147. doi: $10.2307 / 1352563$

Stieglitz, T. C., Clark, J. F., and Hancock, G. J. (2013). The mangrove pump: the tidal flushing of animal burrows in a tropical mangrove forest determined from radionuclide budgets. Geochim. Cosmochim. Acta 102, 12-22. doi: 10.1016/j.gca.2012.10.033

Strangmann, A., Bashan, Y., and Giani, L. (2008). Methane in pristine and impaired mangrove soils and its possible effect on establishment of mangrove seedlings. Biol. Fert. Soils 44, 511-519. doi: 10.1007/s00374-007-0233-7

Tait, D. R., Maher, D. T., Macklin, P. A., and Santos, I. R. (2016). Mangrove pore water exchange across a latitudinal gradient. Geophys. Res. Lett. 43, 3334-3341. doi: 10.1002/2016GL068289

Upstill-Goddard, R. C., Barnes, J., Frost, T., Punshon, S., and Owens, N. J. P. (2000). Methane in the Southern North Sea: low salinity inputs, estuarine removal and atmospheric flux. Glob. Biogeochem. Cycles 14, 1205-1217. doi: 10.1029/1999GB001236

Utsumi, M., Nojiri, Y., Nakamura, T., Nozawa, T., Otsuki, A., Takamura, N., et al. (1998). Dynamics of dissolved methane and methane oxidation in a dimictic Lake Nojiri during winter. Limnol. Oceanogr. 43, 10-17. doi: 10.4319/lo.1998.43.1.0010

Vaghjiani, G. L., and Ravishankara, A. R. (1991). New measurement of the rate coefficient for the reaction of $\mathrm{OH}$ with methane. Nature 350, 406-409. doi: $10.1038 / 350406 \mathrm{a} 0$

Wang, Z. P., Delaune, R. D., Patrick, W. H. Jr., and Masscheleyn, P. H. (1993). Soil redox and $\mathrm{pH}$ effects on methane production in a flooded rice soils. Soil Sci. Soc. Am. J. 57, 382-385. doi: 10.2136/sssaj1993.036159950057000 20016x

Wayne, P. (1991). "The Earth's troposphere," in Chemistry of Atmospheres, An Introduction to the Chemistry of Atmospheres of Earth, the Planets and their Satellites. (Oxford Clarendon Press), 209-275.

Wesely, M. L., and Hicks, B., B. (1977). Some factors that affect the deposition rates of sulfur dioxide and similar gases on vegetation. J. Air Pollut. Control Assoc. 27, 1110-1116. doi: 10.1080/00022470.1977.10470534

Zhang, G. J., Zhang, S., Lui, J., Ren, J., and Xu, F. (2008). Methane in the Changjiang (Yangtze River) Estuary and its adjacent marine area: riverine input, sediment release and atmospheric fluxes. Biogeochemistry 91, 71-84. doi: $10.1007 / \mathrm{s} 10533-008-9259-7$

Zinder, S. H. (1993). "Physiological ecology of methanogens," in Methanogenesis: Ecology, Physiology, Biochemistry and Genetics, ed J. G. Ferry (New York, NY: Chapman \& Hall), 128-206.

Conflict of Interest Statement: The authors declare that the research was conducted in the absence of any commercial or financial relationships that could be construed as a potential conflict of interest.

Copyright $(2017$ Dutta, Bianchi and Mukhopadhyay. This is an open-access article distributed under the terms of the Creative Commons Attribution License (CC BY). The use, distribution or reproduction in other forums is permitted, provided the original author(s) or licensor are credited and that the original publication in this journal is cited, in accordance with accepted academic practice. No use, distribution or reproduction is permitted which does not comply with these terms. 